\title{
BEYOND POWERS AND BRANCHES IN SEPARATION OF POWERS LAW
}

\author{
M. ElizABETH MAGILL ${ }^{\dagger}$
}

\section{INTRODUCTION}

The separation of powers provisions of the Constitution are understood as a way of controlling the exercise of state power by fragmenting it among three different institutions and guaranteeing that fragmentation. Conventional separation of powers analysis relies on two mechanisms to achieve and maintain the dispersal of state power: separating legislative, executive, and judicial power in three different branches and preserving a balance among those branches. These ideas are not just the stuff of high school civics class; legal doctrine governing separation of powers questions is built around them. The first concern about the proper allocation of functions arises in many contexts. The Prison Litigation Reform Act was constitutional only if Congress refrained from invading the judicial power, ${ }^{1}$ and the Environmental Protection Agency's interpretations of the Clean Air Act were legitimate only if they did not represent legislation. ${ }^{2}$ So too with the concern about balance among the branches. Observers claim that the line-item veto upset the balance of authority between the President and the Congress, ${ }^{3}$ the legislative veto aggrandized Congress at

\footnotetext{
${ }^{\dagger}$ Associate Professor, University of Virginia School of Law. For comments and conversation on earlier drafts, thanks to Lillian BeVier, Curtis Bradley, Anne Coughlin, John Harrison, Don Herzog, John C. Jeffries, Jr., Mike Klarman, Daryl Levinson, Richard Merrill, Tom Merrill, Jennifer Mnookin, Glen Robinson, Jim Ryan, Mike Seidman, and Bill Stuntz. Thanks also to participants in the University of Virginia Constitutional Theory Workshop, the University of Michigan Legal Theory Seminar, and Georgetown University Law Center's Faculty Research Workshop. Kendal Aylor, John Butcher, and Jonathon Cornwell provided excellent research assistance. Errors are my own.

1 See Miller v. French, 530 U.S. 327, $341-50$ (2000) (upholding the constitutionality of the Prison Litigation Reform Act because it "does not deprive courts of their adjudicatory role, but merely provides a new legal standard for relief and encourages courts to apply that standard promptly").

${ }_{2}^{2}$ See Whitman v. Am. Trucking Ass'n, 121 S. Ct. 903, 911-14 (2001) ("In a delegation challenge, the constitutional question is whether the statute has delegated legislative power to the agency.").

${ }^{3}$ See $\mathrm{H}$. Jefferson Powell \& Jed Rubenfeld, Laying It on the Line: A Dialogue on Line
} 
the expense of the other branches, ${ }^{4}$ and the growth of the administrative state has shifted the balance of power to the executive. ${ }^{5}$ There is vigorous disagreement about the proper characterization of each of these examples, but there is little controversy about the proper framework within which that debate should proceed.

There should be. The embarrassing secret is that both commitments at the center of separation of powers doctrine are misconceived. The effort to identify and separate governmental powers fails because, in the contested cases, there is no principled way to distinguish between the relevant powers. The available strategies for identifying those differences-and, given the centrality of the question, there are surprisingly few-either rest on formalistic rules that have no content and fail for that reason, or consist of vague normative judgments that cannot work in concrete cases. While there are other possible methods for answering this question that are not yet fully developed in the literature, upon examination, they are not promising. The honest assessment is that we have no way to identify the differences between the powers in contested cases, and we are not likely to have one soon.

The effort to maintain balance among the branches fares no better. An obvious difficulty is that the claims made in the name of interbranch balance-for instance, that a development has upset the balance of power between the branches-are made without conveying why we should care about that balance. Such claims rest on assumed salient differences between the branches of government; the distribution of authority among the branches matters because those institutions will not decide questions in the same way. That intuition about inter-branch difference is taken as truth, but it is weakly supported and open to question. Nonetheless, understanding why we should care about this question is a step forward. It does not, however, rescue the concept. Indeed, it is a hopeless enterprise to talk about balance

\footnotetext{
Item Vetoes and Separation of Powers, 47 DUKE L.J. 1171, 1196 (1998) (stating that the lineitem veto gives the President lawmaking power, and that "it violates the general principle of separation of powers to give such lawmaking power to the President"); Maxwell L. Stearns, The Public Choice Case Against the Item Veto, 49 WASH. \& LEE L. REV. 385, 401 (1992) (“ $[\mathrm{T}]$ he item veto would rework a fundamental shift in the balance of power, providing the President with powerful opportunities to influence the direction and shape of legislative priorities ....").

4 A. Michael Froomkin, The Imperial Presidency's New Vestments, 88 Nw. U. L. REV. 1346, 1368 (1994); Abner S. Greene, Checks and Balances in an Era of Presidential Law making, 61 U. CHI. L. REV. 123, 165 (1994).

${ }^{5}$ Martin S. Flaherty, The Most Dangerous Branch, 105 YALE L.J. 1725, 1819-21 (1996).
} 
among the branches of government. We have not come close to articulating a vision of what an ideal balance would look like. Even if we had tackled that normative question, we have no way to measure the distribution of power among the branches at any point in time and no method to predict the effect of an institutional arrangement. In short, we do not know what balance means, how to measure it, or how to predict when it might be jeopardized. All these deficiencies are partly explained by the final and most fundamental difficulty with this idea. Inquiring about inter-branch balance is incoherent because it assumes that branches of government are unitary entities with cohesive interests, but that is not true. The institutions of the national government are made up of individuals and sub-institutions with varying incentives that do not neatly track the institution within which they are located.

This Article argues that the two central commitments of contemporary separation of powers law are a failure. Fine-tuning these ideas will not redeem them. Rather, the criticisms offered here reveal that we are thinking about questions of horizontal constitutional structure in the wrong way. Talk of balancing three branches exercising three powers may be comfortable, but it is also tired and, more important, unhelpful and in some ways incoherent. Abandoning these ideas, as we must, will make room for new ways of thinking about separation of powers law.

Reconstructing separation of powers law will be no easy task. While this Article cannot complete that effort, it starts it by sketching the implications of the criticisms offered here. Taking seriously the failings of current law offers at least two important lessons for its reconceptualization. The most significant lesson is that if one is interested in fragmenting state power and assuring that it remains fragmented, the failure of the conventional approaches is of little moment. Those approaches seek to disperse the three powers in three balanced branches, in part, so that no single institution controls too much state power. This Article will argue that those efforts fail. But in the course of noticing that there is no such thing as three essential powers exercised by three undifferentiated branches, we will also notice that government authority is fragmented, widely so, albeit not according to the three-powers-in-three-branches formula. Instead, government authority is diffused among a large and diverse set of government decisionmakers who have a hand in the exercise of state power. The extent of that diffusion of state power is more than sufficient to put to rest any concerns about dangerous concentrations of 
government authority. And the character of that fragmentation is such that state power is likely to remain widely dispersed. Because the decisionmakers who share in the exercise of government authority have varied incentives-owing to their diverse constituencies, institutional locations, and ways of doing business-there is little chance that they would collude to concentrate government power in a few hands. If diffusion of state authority is what we are after-and that is what conventional approaches in part are seeking-we have it. To the extent that separation of powers doctrine is driven by worries about the prospect of dangerous concentrations of state power in a single institution of government, those worries are misplaced.

Understanding the character of the distribution of government authority also offers a second lesson for separation of powers law. That law aspires to something more than general diffusion of state power; it seeks to match the exercise of particular powers-legislative, executive, judicial-with corresponding institutions that are best suited to exercise those powers. The criticisms offered here suggest that current efforts go about this ambitious undertaking in exactly the wrong way. Conventional thinking about separation of powers operates as if it is meaningful to talk of powers and branches. There are many flaws in that effort, but one of them is that our system does not operate at those levels; government authority cannot be parceled neatly into three categories, and government actors cannot be understood solely as members of a branch of government. An effort to match particular state powers with particular government decisionmakers must start with an understanding of how those decisionmakers might exercise that authority. That requires a fine-grained appreciation of the forces that push and pull government actors in one direction or another. A doctrine built around such understandings will offer no easy answers, but it will at least ask the right questions.

Part I of this Article presents and criticizes the two central features of current separation of powers thinking. It argues that these ideas fail so completely that they should be abandoned, making room for a reconceptualization of separation of powers law that forgoes reliance on the familiar, but unhelpful, guides of three powers and three branches. Part II starts the reconstruction effort. The criticisms offered here diagnose particular failings of current doctrine and suggest the more promising paths that doctrine should pursue. 


\section{Three SeParated PoWers AND Three Bal ANCED BRANCHES}

Those who analyze separation of powers questions are typically thought to be deeply divided over how to resolve controversies involving the allocation of authority among the departments of the federal government. ${ }^{6}$ It's true, there is debate about the proper method for deciding particular cases-a dispute that tracks the familiar choice between a rule or a standard. ${ }^{7}$ There is also disagreement about what the principle of separation of powers substantively requires. The deepest of these substantive differences are about the organization of the executive branch-whether the Constitution requires that the President control a hierarchically organized executive branch ${ }^{8}$-and the depth of commitment to requiring that each of the branches exercise only the power assigned to that branch, a controversy that largely revolves around the constitutional status of administrative agencies.

But the depiction of disagreement is also inaccurate. The differ-

'See Flaherty, supra note 5, at 1732-44 (describing the different approaches to analyzing the balance of powers among the branches); M. Elizabeth Magill, The Real Separation in Separation of Powers Law, 86 VA. L. REV. 1127, 1136-47 (2000) (setting forth the debate between formalist and functionalist approaches to separation of powers); Thomas W. Merrill, The Constitutional Principle of Separation of Powers, 1991 SUP. CT. REV. 225, 226-35 (explaining the Supreme Court's two conceptions of separation of powers, the "formal" and "functional" approaches).

7 Merrill, supra note 6, at 230.

${ }^{8}$ The literature about the unitary executive is enormous. For a sampling of the literature arguing that the Constitution establishes a unitary executive, see Steven G. Calabresi \& Saikrishna B. Prakash, The President's Power to Execute the Laws, 104 YALE L.J. 541 (1994); Steven G. Calabresi \& Kevin H. Rhodes, The Structural Constitution: Unitary Executive, Plural Judiciary, 105 HARV. L. REV. 1153 (1992); Gary Lawson, The Rise and Rise of the Administrative State, 107 HARV. L. REV. 1231 (1994). For a sampling of the literature taking the opposing position, see Flaherty, supra note 5; Froomkin, supra note 4; A. Michael Froomkin, Note, In Defense of Administrative Agency Autonomy, 96 YALE L.J. 787 (1987). See also Lawrence Lessig \& Cass R. Sunstein, The President and the Administration, 94 ColuM. L. REV. 1 (1994) (arguing that historical record does not demonstrate that support for a unitary executive originated with the Framers themselves).

${ }^{9}$ David P. Currie, The Distribution of Powers After Bowsher, 1986 SUP. CT. REV. 19, 20; Lawson, supra note 8, at 1232; see Geoffrey P. Miller, Independent Agencies, 1986 SUP. CT. REV. 41, 96-97 (arguing that administrative agencies are "anomalous institution [s] created without regard to the basic principle of separation of powers upon which our government was founded"); Peter L. Strauss, The Place of Agencies in Government: Separation of Powers and the Fourth Branch, 84 COLUM. L. REV. 573, 667 (1984) (arguing that administrative agencies can be reconciled with constitutional values if they are supervised by a politically accountable chief executive and structured to encourage rivalries among the three heads of government). 
ing approaches serve the same overarching goal: cabining the exercise of state power by fragmenting that power among three distinct and potent branches of government. The commonalities run deeper than adherence to this general goal. Dominant academic approaches subscribe to specific postulates to achieve that goal and those same postulates are central to judicial approaches to separation of powers. The courts and most commentators are committed to distinguishing, in at least some range of cases, among legislative, executive, and judicial powers and assuring that (barring a textual exception to that assignment) these three functions are separately exercised by the corresponding branch of government. Courts and most commentators are also committed to assuring that no one branch of government can dominate the others, thereby preserving some rough balance of authority among the branches or, as the idea is sometimes articulated, to prevent the aggrandizement of one branch at the expense of another. It is predictable that these two commitments would constitute the backbone of current approaches to separation of powers. They are derived from the well-known provisions of the Constitution: the vesting of three governmental functions in three distinct branches of government, and the so-called "checks" (veto, advice and consent, and impeachment) that represent departures from that separation.

This common ground would be a helpful starting point for further analysis if it were sensible. Unfortunately, it is not. This section analyzes and criticizes each of the commitments.

\section{A. Three Separated Powers}

The identification and separation of the three functions of government is a central tenet of most approaches to separation of powers law. ${ }^{10}$ Two approaches compete for primacy in the caselaw and the commentary. One approach, often dubbed formalist, emphasizes that the Constitution divides governmental power into three categories and, with some explicit textual exceptions, assigns those powers to three different branches of government. When confronting an institutional arrangement, a formalist, following a rule-like approach,

${ }^{10}$ Approaches that urge courts to treat structural questions as nonjusticiable political questions do not depend on an ability to articulate, for purposes of judicial enforcement, the differences between the three functions of government. See JESSE H. CHOPER, JUdicial RevieW AND THE NATIONAL PolitiCAl Process 260-379 (1980) (arguing that judicial review is not necessary for separation of powers cases). This is a distinct minority view in the literature and, as its continued consideration of separation of powers cases indicates, has been rejected by the Supreme Court. 
identifies the type of power exercised and asks whether it is exercised by the appropriate department in the appropriate way." The competing approach, usually called functionalism, emphasizes that the departments of government have shared and overlapping powers, as well as separate powers. Under this approach, the key question is whether an institutional arrangement upsets the overall balance among those branches by permitting one of them to compromise the "core" function of another. ${ }^{12}$ There are, to be sure, some academic commentators who resist these schools of thought. ${ }^{13}$ But the Supreme Court vacillates back and forth between the two dominant approaches, relying on something resembling the formalist approach to invalidate certain arrangements-the line-item and legislative vetoes-and something

1 See Martin H. Redish, The Constitution as Political Structure 99-134, 101 (1995) ("[T] Court's role in separation-of-powers cases is to be limited to determining whether the challenged branch action falls within the definition of that branch's constitutionally derived powers . ..."); Lawson, supra note 8, at 1237-41 ("The institutions of the national government are creatures of the Constitution and must find constitutional authorization for any action.").

${ }^{12}$ See Peter L. Strauss, Formal and Functional Approaches to Separation-of-Powers Questions-A Foolish Inconsistency?, 72 CoRNELL. L. REV. 488, 489 (1987) ("[A] functional approach ... stresses core function and relationship, and permits a good deal of flexibility when these attributes are not threatened."); Strauss, supra note 9, at 579 ("[Maintaining] the intended balance and interaction among the three named actors ..., with each continuing to have effective responsibility for its unique core function, depends on the existence of relationships between each of these actors .... [W] should stop pretending that all our government ... can be allocated into three neat parts."); see also Harold H. Bruff, Presidential Power and Administrative Rulemaking, 88 YALE L.J. 451, 453 (1979) (discussing the application of separation of powers review to presidential involvement in rulemaking and suggesting that "the Court should take a more flexible approach" and consider "whether the other branches can effectively exercise their checks").

${ }^{13}$ Some of these approaches are discussed in Magill, supra note 6, at 1146-47. See, e.g., Rebecca L. Brown, Separated Powers and Ordered Liberty, 139 U. PA. L. REv. 1513, 1515-16 (1991) (arguing that “ $[\mathrm{t}]$ he protection of individual rights ... should be an explicit factor in the analysis of structural issues and should provide an animating principle for the jurisprudence of separated powers"); Laura S. Fitzgerald, Cadenced Power: The Kinetic Constitution, 46 DUKE L.J. 679, 683 (1997) (offering a separation of powers approach that focuses on the political constituencies of each branch of government and the sequence of decision making set forth in the Constitution); Harold J. Krent, Separating the Strands in Separation of Powers Controversies, 74 VA. L. REv. 1253, 1322-23 (1988) (offering an approach built around limits the Constitution prescribes for each branch); Merrill, supra note 6, at 228 (offering a 'minimal' approach that requires every federal office to be located in one of the three branches and thus subject to whatever limitations that apply to that branch); Victoria Nourse, The Vertical Separation of Powers, 49 DUKE L.J. 749, 757-60 (1999) (offering an approach that considers the constituency relationships of the officials who will exercise power); Paul R. Verkuil, Separation of Powers, the Rule of Law and the Idea of Independence, 30 WM. \& MARY L. REV. 301, 303-22 (1989) (offering an approach focused on preventing conflicts of interest). 
similar to functionalism to validate other arrangements-the independent counsel statute, the exercise of adjudicatory authority by administrative agencies. ${ }^{14}$

The focus on the differences between these schools of thought obscures their similarities. Both are committed to dispersal of the three governmental functions among the corresponding three governmental institutions. ${ }^{15}$ For the formalist, this commitment is obvious. It is crucial, on that understanding, that the executive department exercise executive power and no other, Congress exercise legislative power and no other, and the courts exercise judicial power and no other. ${ }^{16}$ Professor Redish, for example, explains that under his approach,

the Court's role in separation-of-powers cases is to be limited to determining whether the challenged branch action falls within the definition of that branch's constitutionally derived powers-executive, legislative or judicial. If the answer is yes, the branch's action is constitutional; if the answer is no, the action is unconstitutional. No other questions are to be asked; no other countervailing factors are to be taken into account.

Although this premise of their approach is usually ignored, functionalists are likewise committed to a division of governmental author-

14 Magill, supra note 6, at 1138 \& n.37; Merrill, supra note 6, at 226.

${ }^{15}$ Merrill, supra note 6 , at 231; see Nourse, supra note 13, at $754 \mathrm{n} .24$ (observing that the commitment to the identification and separation of government functions can be found even among commentators who present alternative approaches to separation of powers).

${ }_{16}$ REDISH, supra note 11, at 99-134; Calabresi \& Prakash, supra note 8, at 559-60; Currie, supra note 9, at 19; Lawson, supra note 8, at 1237-38; see Lee S. Liberman, Morrison v. Olson: A Formalistic Perspective on Why the Court Was Wrong, 38 AM. U. L. REv. 313, 315 (1989) (writing that the Supreme Court was wrong in upholding the constitutionality of the independent counsel statute because the Constitution "grants the President the entire executive power of the United States, and grants it to him alone").

${ }^{17}$ REDisH, supra note 11, at 101; see also id. at 100 ("[The formalist] approach ... [is] grounded on the deceptively simple principle that no branch may be permitted to exercise any authority definitionally found to fall outside its constitutionally delimited powers."). Much the same can be said about other formalist commentators. Consider Professor Calabresi's explanation of his understanding of the Constitution's requirements:

[A]ny governmental power exercised in our system must be either legislative or executive or judicial: the premises of the system do not allow for the conclusion that a power could be something other than one of these three (or that it could be two of them at the same time).

Steven G. Calabresi, The Vesting Clauses as Power Grants, 88 Nw. U. L. REv. 1377, 1390 (1994). The rules Professor Gary Lawson extracts from the Constitution are similar: "The Constitution thus divides the powers of the national government into three categories-legislative, executive, and judicial-and vests such powers in three separate institutions." Lawson, supra note 8, at 1237. 
ity among the branches. While a functionalist would be flexible-in particular, tolerating the exercise of "judicial" or "legislative" power by an administrative agency-as long as a "core" function of the department in question was not jeopardized, ${ }^{18}$ they agree with formalists that the Constitution allocates three different powers to three different institutions. The leading exponent of this approach would follow a rigid requirement of functional separation with respect to the three actors named in the Constitution; as among them, "only Congress may legislate, only the Supreme [Court] may adjudicate, and only the President may see to the faithful execution of the laws." ${ }^{19}$ And, the flexibility of functionalism evaporates if the arrangement threatens "core" functions. But to preserve core functions, one has to have an idea of just what they are. In short, as Professor Thomas Merrill has correctly observed, both schools of thought "generally agree with the traditional understanding that governmental activities can be classified under three functional headings-legislative, executive, or judicial-with each function associated with one of the three branches of government. ${ }^{20}$

${ }^{18}$ Strauss, supra note 12 , at 489 ; see Strauss, supra note 9, at 579 ("[The] goal is intended balance and interaction among the three named [constitutional] actors at the top of government, with each continuing to have effective responsibility for its unique core function ...."); see also Bruff, supra note 12, at 486-88 ("[T] he flexible approach [applied to the President's role in agency rulemaking] must be characterized by estimations of the balance in given circumstances between the President's concerns and the countervailing interests of the other branches and of the people."). The analysis contained in certain Supreme Court decisions conforms to what commentators describe as functionalist analysis. See Morrison v. Olson, 487 U.S. 654, 689-96 (1988) (" $[\mathrm{T}]$ he real question is whether the removal restrictions [applicable to independent counsel] are of such a nature that they impede the President's ability to perform his constitutional duty. ..."); Nixon v. Fitzgerald, 457 U.S. 731, 753-54 (1982) ("[A] court, before exercising jurisdiction [over the President], must balance the constitutional weight of the interest to be served against the dangers of intrusion on the authority and functions of the Executive Branch."); Nixon v. Adm'r of Gen. Servs., 433 U.S. 425, 441-46 (1977) (" $[\mathrm{I}] \mathrm{n}$ determining whether the [Presidential Recordings and Material Preservation] Act disrupts the proper balance between the coordinate branches, the proper inquiry focuses on the extent to which it prevents the Executive Branch from accomplishing its constitutionally assigned functions."); United States v. Nixon, 418 U.S. $683,706-07$ (1974) ("Since we conclude that the legitimate needs of the judicial process may outweigh Presidential privilege, it is necessary to resolve those competing interests in a manner that preserves the essential functions of each branch.").

${ }^{19}$ Strauss, supra note 9 , at 596.

${ }^{20}$ Merrill, supra note 6, at 231; see also id. at 235 (referring to "the shared preoccupation [of formalists and functionalists] with the functional classification of government activities"). Victoria Nourse has made the same observation:

It is a widely held view, common to a variety of theoretical positions, that the three departments serve different functions and that these functional distinctions are essential to preserve the separation of powers. Assumed, here, is the 
To assure the institutionally separate exercise of governmental functions, as courts and many commentators seek to do, one must be able to identify the differences among those functions. To state the obvious, the Constitutional terms are far from self-defining. Moreover, there is no well-accepted doctrine or theory that offers a way to identify the differences among the governmental functions in contested cases. Indeed, given that the doctrine and many theoretical approaches profess commitment to the separation of the three functions, the remarkable fact about the doctrine and literature is that very little of it is devoted to identifying their contours. The sporadic judicial efforts to identify the differences among the governmental powers are nearly universally thought to be unhelpful. ${ }^{21}$ The Supreme Court's attempt, for instance, to define legislative power in order to assess the constitutionality of the legislative veto was widely viewed as unsuccessful. $^{22}$ In INS v. Chadha, the Court held that the House's veto

idea that " $[\mathrm{t}]$ he executive Power," the "legislative Powers," and " $[\mathrm{t}]$ he judicial Power" represent different kinds of power readily distinguishable in theory, if not in practice. ... [T] his idea of "functional" separation is implicit in positions ranging from the left to the right, from originalists to realists, and from formalists to critical pragmatists.

Victoria Nourse, Toward a "Due Foundation" for the Separation of Powers: The Federalist Papers as Political Narrative, 74 TEX. L. REV. 447, 493 (1996) (first and second alterations in original) (footnotes omitted).

${ }^{21}$ See Flaherty, supra note 5, at 1735-36 (noting the Supreme Court's difficulty with specifying the nature of a given power); Nourse, supra note 13 , at $754,757 \& \mathbf{n} .21$ ("The Supreme Court openly quarrels about how to characterize . . . a single activity as executive, judicial, and legislative."). In several cases, the Supreme Court has attempted to define the functions of government. See Whitman v. Am. Trucking, 121 S. Ct. 903, 911-14 (2001) (rejecting the claim that the Clean Air Act unconstitutionally delegated legislative power without defining legislative power); $i d$. at 920-21 (Stevens, J., concurring) (disagreeing with the Court's characterization and arguing that the agency exercised legislative power); Plaut v. Spendthrift Farm, 514 U.S. 211, 219-40 (1995) (defining judicial power as the power to make dispositive judgments); Metro. Wash. Airports Auth. v. Citizens for the Abatement of Aircraft Noise, Inc., 501 U.S. 252, 276-77 (1991) (refusing to characterize the type of power exercised; power is either executive or legislative and, either way, its exercise is unconstitutional); INS v. Chadha, 462 U.S. 919, 952, 960, 1001-02 (1983) (characterizing the legislative veto as an exercise of legislative power though the concurrence described it as akin to adjudicative action, and the dissent described it as congressional action to limit the exercise of legislative power by the agency); see also infra note 28 (citing cases discussing the Supreme Court's difficulty identifying the differences between the three branches of government).

${ }^{22}$ See E. Donald Elliott, INS v. Chadha: The Administrative Constitution, the Constitution, and the Legislative Veto, 1983 SUP. CT. REV. 125, 134-35 ("The Court's presumption that the legislative veto is an exercise of Article I legislative power should only frame, rather than decide, the issue."); Merrill, supra note 6, at 233 (observing that commentators had a field day lampooning the Court's reasoning that the House's veto was a 
altered Mr. Chadha's legal rights and therefore constituted the exercise of legislative power that had to be approved by both houses of Congress and presented to the President. ${ }^{23}$ It reached that conclusion, however, only by contestably defining Mr. Chadha's legal rights prior to the exercise of the legislative veto.

Nor have commentators developed ways of distinguishing among the three powers of government. In fact, the dominant responses to the need to distinguish among the three powers are to ignore the question or confess inadequacy to the task. Functionalist commentators, for their part, leave the three categories of governmental power undefined, including the identification of the "core" functions of each of the departments. And many formalist commentators confess inadequacy to the task: "A meaningful discussion of the definition of the elusive term 'executive power' is beyond the scope of this Article. ${ }^{25}$

This lack of attention does not reflect some nascent consensus about the meaning of these terms. All, in fact, acknowledge that the lines among the three powers are, to understate the point, elusive. ${ }^{26}$

legislative act).

${ }^{23}$ Chadha, 462 U.S. at 952.

${ }^{24}$ Donald Elliott explains this point:

The legislative veto "alters legal rights," however, only because the Court chooses to characterize its effect that way. The Court's manipulation of legal categories could just as easily be turned to support the opposite conclusion that the legislative veto does not alter legal rights.... If Chadha's only right was what the statute gave him-the right to remain in the country unless one house exercised its legislative veto-then the House's action did not alter Chadha's rights: the possibility of a legislative veto was built into them in the first place.

Elliott, supra note 22, at 134-35.

${ }^{25}$ Calabresi \& Rhodes, supra note 8, at 1165 n.52; see also Calabresi, supra note 17, at $1390 \mathrm{n} .47$ ("I do not think I can attempt to address here the very difficult question of whether to seek the original meaning of [the terms executive, legislative, or judicial], their present day meaning, or their original meaning as 'translated' into the present day world."); Lawson, supra note 8, at 1239, 1242 (suggesting that it is often difficult to distinguish between the executive and legislative powers).

${ }^{26}$ We can dispense with some suggestions for the differences among the powers without much effort. Although it is often said, it cannot be that the legislative power is concerned with resolving important policy questions, while the executive power is merely ministerial and technical. Consider the following example: Congress criminalizes the sending of deceptive materials through the mail. The U.S. Justice Department decides not to prosecute those who send solicitations for time shares through the mail, even though there is a colorable argument that the information contained in the mail ings is deceptive. Certainly, most would say that that decision is execution of the law, but it is a policy choice that is hardly unimportant or technical. See REDISH, supra note 11 , at 117-18 (emphasizing that the executive branch should not be confined to minis- 
Madison famously admonished: "Experience has instructed us that no skill in the science of government has yet been able to discriminate and define, with sufficient certainty, its three great provinces-the legislative, executive and judiciary ...." ${ }^{27}$ Nor are our contemporaries any more confident of their ability to define the differences among the three governmental powers. ${ }^{28}$ Professor Gary Lawson, among others, admits that " $[t]$ he problem of distinguishing the three functions of government has long been, and continues to be, one of the most intractable puzzles in constitutional law." ${ }^{29}$

To be fair, there may be a nascent consensus that some exercises of government authority can be pegged as executive, legislative, or judicial. $^{30}$ It is easy enough to define the essence of the three government functions in abstract terms. The legislative power is the specification of the basic norms that govern behavior; the executive power includes the implementation of those laws; and the judicial power is the adjudication of disputes that arise under the laws. And some specific exercises of government authority seem to fall easily in one box or another. When the executive issues a check to pay for a federal road authorized by a statute, that, most would agree, is the exercise of executive authority. When Congress approves the underlying statute

terial functions without any room for creativity, judgment, or discretion).

${ }^{27}$ The Federalist No. 37, at 228 (James Madison) (Clinton Rossiter ed., 1961).

${ }^{28}$ See Clinton v. New York, 524 U.S. 417, 480-81 (1998) (Breyer, J., dissenting) (stating that the Supreme Court cannot define the difference between the legislative and executive powers with perfect precision). In Bowsher v. Synar, Justice Stevens explained how difficult it is to label powers:

One reason that the exercise of legislative, executive, and judicial powers cannot be categorically distributed among three mutually exclusive branches of Government is that governmental power cannot always be readily characterized with only one of those three labels. On the contrary, as our cases demonstrate, a particular function, like a chameleon, will often take on the aspect of the office to which it is assigned.

478 U.S. 714, 749 (1986) (Stevens, J., concurring in judgment); see also William B. Gwyn, The American Constitutional Tradition of Shared and Separated Powers: The Indeterminacy of the Separation of Powers in the Age of the Framers, 30 WM. \& MARY L. REv. 263, $267-$ 68 (1989) (stating that judges should have little confidence in their ability to identify the differences between the governmental powers).

${ }^{29}$ See Lawson, supra note 8, at 1238 n.45; see also Calabresi, supra note 17, at 1390 n.47 (1994) ("I do not disagree that the task is difficult or that the terms 'executive,' 'legislative,' and 'judicial' power lack a completely coherent independent meaning as a matter of either political science or history."). The leading functionalist commentator also admits to the "imprecision inherent in the definition and separation of the three governmental powers." Strauss, supra note 9, at 603 .

3) See Gary Lawson, Delegation and the Constitution, 22 Regulation, Nov. 2, 1999, at 23,25 (stating that even though there is no precise definition of executive power, this does mean that there are no boundaries between the three governmental functions). 
authorizing that road expenditure, most would agree that that is the exercise of legislative authority. Even assuming the existence of some core of each of the government functions, however, its existence is of little help in contested cases. A change in the previous example asks the nondelegation question: Could Congress, instead of deciding by statute where roads should be built, authorize the executive to design an efficient and useful national transportation infrastructure-federal roads, railroad tracks, and airline routes? Or consider other examples: Is the legislative veto the exercise of legislative power? Do administrative agencies improperly exercise judicial power when they adjudicate controversies? Would a statute that constrains prosecutorial discretion invade the executive power? None of these situations involves the uncontested core of the government functions. Yet, if one is committed to functional separation, these cases must be properly sorted into one category of power or another.

Perhaps there is a good explanation for this near silence on so basic a question. One might argue that there is no need for a fully developed theory about the differences among the three government functions in order to know whether certain contested arrangements are constitutional. Consider the example of Bowsher $v$. Synar, a case involving the constitutionality of the comptroller general's role in the Gramm-Rudman-Hollings deficit reduction scheme. ${ }^{31}$ Under the Act, the comptroller general was to prepare a report containing estimates of the projected revenues and expenditures for the fiscal year. If the comptroller projected a deficit, the report was to specify the spending cuts that would be necessary to reduce the deficit to a pre-established target. That report would be sent to the President, who would, under the Act, be obligated to carry out the spending reductions outlined in the report. ${ }^{32}$ One could argue that, regardless of the type of power the comptroller general exercised when he reported his budgetary conclusions to the President, the way in which it was exercised did not satisfy any of the relevant constraints. If the actions of the comptroller general constituted the exercise of legislative power, it had not been bicamerally approved, and if it was the exercise of executive power, it was not being exercised by an individual appointed pursuant to the Appointments Clause. ${ }^{33}$ In such a case, there is no need to identify

${ }^{31} 478$ U.S. at 740.

${ }^{32}$ Id. at $718,732-33$.

${ }^{33}$ See Krent, supra note 13, at 1280-81 (analyzing the implications of characterizing the powers exercised by the comptroller general as legislative/executive). Compare Bowsher, 478 U.S. at 723-36 (majority opinion) (holding that the comptroller general's 
the type of power exercised by the comptroller general because, no matter how characterized, the arrangement is unconstitutional.

The tactic may be neat but it is not satisfying. Eluding the characterization question may be a way to defend an outcome on a particular set of facts, but it does little else. At a conceptual level, the strategy is an odd one for those who are committed to the separation of government functions. They argue that it is important for the three functions of government to be separated institutionally from one another. If one fails, however, to identify the type of government function at issue in cases, the content of those three categories will remain underdeveloped. If we avoid such questions, how could we be sure that we are institutionally separating functions? Such a failure might be acceptable if one is skeptical of, or agnostic about, the importance of the institutional separation of functions. But adherents of the dominant approaches are not.

More practically, the avoidance strategy fails to provide guidance in a range of controversial and consequential cases. Consider the boundary between executive and legislative power. There are cases where the executive acts in ways that affect the rights and duties of those outside the executive branch-as for example, in the promulgation of so-called legislative rules under the Administrative Procedure Act, ${ }^{34}$ or in the adoption of certain executive orders. ${ }^{35}$ A formalist

exercise of executive power violates the presidential removal power), with Bowsher, 478 U.S. at 737 (Stevens, J., concurring in judgment) (arguing that the comptroller general's exercise of legislative power violates constitutional requirements of bicameralism and presentment). The Supreme Court relied on this strategy in Metropolitan Washington Airports Authority v. Citizens for the Abatement of Aircraft Noise, Inc., 501 U.S. 252 (1991). There, the lower court had characterized the entity at issue in the case as exercising quintessentially executive power. The Court, however, observed that resolving the characterization issue was not necessary because, no matter how characterized, the entity was unconstitutional: "If the power is executive, the Constitution does not permit an agent of Congress to exercise it. If the power is legislative, Congress must exercise it in conformity with the bicameralism and presentment requirements of Art. I, $\S$ 7." Id. at 276.

54 U.S.C. $\$ 553$ (1994).

${ }^{35}$ See, e.g., Exec. Order No. 11,246, 3 C.F.R. 339 (1964-1965) (President Johnson's order requiring affirmative action contract provisions for all government contractors); Exec. Order No. 11,063, 3 C.F.R. 652 (1959-1963) (President Kennedy's order requiring nondiscrimination in housing owned, operated, or financed by the federal government); Exec. Order No. 10,479, 3 C.F.R. 961 (1949-1953) (President Truman's order requiring nondiscrimination clauses in government contracts). More recent executive orders also affect the rights of private parties. See, e.g., Exec. Order No. 12,954, 3 C.F.R. 329 (1996) (President Clinton's order allowing debarment of contractors that permanently replace striking employees); Exec. Order No. 12,933, 3 C.F.R. 927 (1995) (President Clinton's order requiring successor federal contractors to offer 
court confronting such cases would be forced to determine whether the executive is "executing" or "legislating." The inquiry would be slightly different for a functionalist, but the characterization question would remain; a functionalist court would have to determine whether the action by the executive compromised the "core" functions of Congress or the judiciary. A similar problem occurs from the other angle: legislative action that arguably intruded on an executive power by directing the way in which that power would be exercised. ${ }^{36}$ The War Powers Resolution is a prominent example of this problem, ${ }^{37}$ and other actions fit the pattern as well. ${ }^{38}$ Consider a statute controlling the exercise of prosecutorial discretion. The exercise of prosecutorial discretion is thought by some to be at the core of executive power. ${ }^{39} \mathrm{~A}$ formalist would have to decide whether a zone of prosecutorial discretion was part of the executive power and whether, through the statute, Congress had impermissibly infringed on that power. Likewise, a functionalist would have to ask whether a zone of prosecutorial discretion was part of a "core" executive function and, if so, whether the statute impermissibly infringed on the exercise of that core function.

right of first refusal to employees under predecessor contractor), revoked by Exec. Order No. 13,204, 66 Fed. Reg. 11,228 (Feb. 22, 2001).

${ }^{36}$ This same problem arises in the context of the boundary between legislative and judicial power. See Miller v. French, 530 U.S. 327, 344-350 (2000) (holding that through the Prison Litigation Reform Act of 1995 Congress did not encroach upon the powers of the judiciary); Plaut v. Spendthrift Farm, 514 U.S. 211, 240 (1995) (holding section 27A(b) of the Securities Exchange Act of 1934 unconstitutional because it requires federal courts to reopen final judgments entered before its enactment, thus destroying separation of powers); see also John Harrison, The Power of Congress over the Rules of Precedent, 50 DuKE L.J. 503, 539-43 (2000) (analyzing whether a statute governing rules of precedent in federal courts would constitute an unconstitutional intrusion on judicial power).

${ }^{37}$ See JOHN HART ELY, WAR AND RESPONSIBILITY: CONSTITUTIONAL LESSONS OF VIETNAM AND ITS AFTERMATH 60-63 (1993) (defending the constitutionality of most provisions of the War Powers Resolution against the common charge that the Resolution unconstitutionally interferes with the exercise of executive power).

${ }^{38}$ John Harrison identifies an excellent example of this problem. See Harrison, supra note 36, at $541 \mathrm{n} .111$ (citing "a provision in the Army appropriation act for 1868 providing that all orders from the president or secretary of war to the armed forces were to be given through the General of the Army, then U.S. Grant").

${ }^{39}$ See Morrison v. Olson, 487 U.S. 654, 705-06 (1988) (Scalia, J., dissenting) ("Governmental investigation and prosecution of crimes is a quintessentially executive function."). But see Stephen L. Carter, Comment, The Independent Counsel Mess, 102 Harv. L. ReV. 105, 126 (1988) (noting historical examples contradicting the claims that prosecution is a core executive function); Krent, supra note 13, at 1319 ("Historically, Congress has fragmented control over criminal law enforcement within the executive branch ... and vested some investigative and prosecutorial authority in state officials and private individuals outside the control of the executive."). 
If this strategy of avoiding the definitional question is not satisfactory, one must be prepared to identify the differences among the functions of government. But there are no promising proposals for addressing this question in either the current caselaw or commentary. ${ }^{40}$ It is worth starting with the most simple definitions of the three powers, ${ }^{41}$ if only to see that they are not particularly helpful. Under these definitions, legislative power is the making of general rules that govern the rights and obligations of parties outside the legislature; the general executive power-as opposed to the specifically enumerated executive powers-includes the power to implement the rules enacted by the legislature; and the judicial power is the application of those rules in individual cases. ${ }^{42}$

Focus on the distinction between legislative and executive power. ${ }^{43}$ Both creating and implementing the law can govern individuals' rights and obligations and thus that feature does not usefully distinguish legislative from executive power. For example, consider the granting of licenses. Congress authorizes the Federal Energy Regulatory Commission (FERC) to grant licenses when they are "in the public interest" and sets forth a list of factors that indicate when the li-

${ }^{40}$ This section of the Article does not focus heavily on the ways that courts have offered to distinguish among the powers because the point made in the text about the caselaw is well accepted. See, e.g., Flaherty, supra note 5, at 1735-36 (stating that current caselaw makes it difficult for both functionalists and formalists to categorize the branches of government); Geoffrey P. Miller, Rights and Structure in Constitutional Theory, 8 SOC. PHIL. \& POL'y 196, 202 ("The [Supreme Court's] model implicitly draws on a theory of core functions; to date, however, the Supreme Court has failed to shed much light on what that theory might be."); Nourse, supra note 13, at 754-57 (arguing that the Supreme Court is unable to identify clear lines among the three government functions).

41 I focus here on what one might call the general powers allocated by the Vesting and Take Care Clauses in the Constitution. Thus, with respect to the executive power, for instance, I do not mean to focus on the power of the commander in chief, but rather on the general executive power and the power to take care that the laws are faithfully executed.

${ }^{42}$ See W.B. GWYN, The Meaning of the SeParation of POWERs 103 (1965) (describing Montesquieu's formulation, as "[1]egislative power is concerned with making general rules of conduct; executive power carries out the laws; . . judicial power determines how the laws affect particular persons in particular circumstances").

${ }^{43}$ The boundaries between executive and judicial powers, or legislative and judicial powers, are no less difficult. The Court is also occasionally asked to police those boundaries. See Miller v. French, 530 U.S. 327, 341-50 (2000) (legislative/judicial boundary); Plaut v. Spendthrift Farm, 514 U.S. 211, 219-25 (1995) (same); Commodity Futures Trading Comm'n v. Schor, 478 U.S. 833, 857-59 (1986) (cxecutive/judicial boundary). For a powerful analysis of the appropriate boundary between legislative and judicial power in the context of congressional authority over the rules of precedent, see Harrison, supra note 36. 
cense would be in the public interest. ${ }^{44}$ In determining which of the various applicants should obtain a license, the FERC would be implementing that law. And, just as clearly, by granting or denying a license, the FERC would govern the rights and obligations of a third party.

Nor is it the "general" part of governing rights and obligations that makes legislative power different from executive power. One might argue that only Congress can generally govern the rights and obligations of private individuals by creating a norm for a class of actors-all those seeking hydropower licenses, for instance. Executive action, on this theory, is limited to the application of legislatively created norms in individual cases-whether a specific applicant qualifies for a license, for instance. This definition, however, depends on an arbitrary distinction between individual and general rules. Consider a rule developed by the FERC pursuant to statute that requires all hydropower license applicants to include in their applications information about the effect of their dams on fisheries. That rule governs the rights and obligations of the whole class of license applicants. While one could take the view that executive action cannot so govern the rights and obligations of a class, ${ }^{45}$ it is arbitrary to draw the line demarcating legislative from executive action at that point. If execution of the law may permissibly govern the rights and obligations of individuals-classically, the grant or denial of a license-then there does not appear to be a reason to conclude that general rules of the same character are outside of the executive power. It seems just as plausible that an executive action could include the development of general rules that further fill out the details-and, in that way, implement-a legislative enactment.

${ }^{44}$ The statute directs the FERC to consider the following: 1) the purposes of energy conservation; 2) the protection, mitigation of damage to, and enhancement of fish and wildlife (including related spawning grounds and habitat); 3) the protection of recreational opportunities; and 4) the preservation of other aspects of environmental quality in addition to the power and development purposes for which licenses are issued. 16 U.S.C. $\$ 797$ (e) (1994).

${ }^{45}$ Similar reasoning lies behind an oft-made, but differently phrased, argument. It is sometimes said that actions taken by administrative agencies-such as the promulgation of rules under the Administrative Procedure Act-is legislative in the sense that the legislature itself could have enacted the rule as a statute. See Saikrishna Bangalore Prakash, Deviant Executive Lawmaking, 67 GEO. WASH. L. REv. 1, 15 n.96 (1998) ("In my view, delegated discretion is delegated legislative power, because in most instances, Congress could have withdrawn (at least in part) that discretion.") But this characterization is dependent on the assumption-not independently defended-that any general rule governing the rights and obligations of third parties is, ipso facto, an exercise of the legislative power. 
More elaborate efforts to identify the differences between legislation and execution are no more promising. Commentators offer two types of arguments that track the typical choice between rules and standards. These arguments suffer from obvious failings: the rule-like approach is too superficial to do work in hard cases and the standardlike approach is too general to be of use.

Consider first the proceduralist approach that some courts and commentators offer. To determine whether the exercise of a government power is legislative, executive, or judicial, a number of observers attach significance to the process by which that power is exercised. $^{46}$ As Professor Calabresi explains:

[T] here is actually a way by which we can tell what exercises of governmental power are "legislative" or "judicial." Governmental actions of these types can only be performed if certain procedural prerequisites are met: bicameralism and presentment (in the case of legislation), litigation of a case or controversy (in the case of adjudication).

This position is critically incomplete. Take the example of legislative power. Bicameralism and presentment may be necessary to the enactment of laws. But bicameralism and presentment are obviously not sufficient for the exercise of legislative power. If they were, then Congress could decide an individual case so long as it did so bicamerally and presented it to the President. While Calabresi seems to recognize this problem, ${ }^{48}$ he does little to address it.

This approach fails because it tries to follow form and ignore con-

${ }^{46}$ Calabresi, supra note 17 , at 1391 . Others, such as Professor Redish, make similar arguments.

[T] he difference is the structural "baggage" that the exercise of the judicial and executive powers are required to carry-baggage which does not affix itself to the exercise of the legislative power. . . Indeed, that it is, at least to a large extent, the procedural and structural context in which a policy choice is made-rather than the substance of that choice-that distinguishes the legislative and judicial functions is demonstrated by the fact that, on nonconstitutional issues, Congress may overrule judicially created substantive rules that have been fashioned in the context of case adjudication.

REDISH, supra note 11, at 117; see also Liberman, supra note 16, at 323 ("The legislative and executive branches make all three kinds of decisions[: policy determinations, pure interpretation, and carrying in to effect of some existing rule] ... [T] he type of power being exercised depends on whether the decision is made in the course of writing a law, executing a law, or deciding a case." (footnotes omitted)).

${ }^{47}$ Calabresi, supra note 17, at 1391 (footnotes omitted).

${ }^{48}$ As Calabresi makes clear while discussing the full contours of executive power, the approach he describes does not mean that "the President can take any governmental action he wants, so long as he does not follow the procedural hoops of Article I, Section 7 or of Article III, Section 2." Id. (emphasis omitted). 
tent. But such content is a necessary component of the line between legislation and execution. Commentators offer some guidance here, but it falls far short of filling the gap. Consider, for example, Professor Calabresi's attempt to define the line between execution and legislation for purposes of the nondelegation question: "there are things that affect private rights to such a degree, and that so traditionally have been done by the legislature, and that so thoroughly partake of general rulemaking that they simply must be done by Congress or not at all." Calabresi specifies some examples that fall in the category of legislation: seizing steel mills, promulgation of codes of fair competition, and setting the budget of the United States. ${ }^{50}$ It is not clear whether these examples satisfy some or all of the criteria. Nor is it clear what we are to do if the criteria suggest different outcomes. Examining the factors more closely also raises questions about each. Consider the "traditionalness" of an action. There are familiar normative and descriptive difficulties with this criterion. Why should the fact that Congress has traditionally done something mean that it must continue to do so? Could a change in circumstances ever warrant a change in practice, and, if so, when would we know that such a change has occurred? Descriptively, at what level of generality should that tradition be discerned?

The two other parts of the test are no more satisfactory. If promulgating codes of unfair competition must be done by Congress, then the Sherman $\mathrm{Act}^{51}$ would seem to be unconstitutional. It amounts to a statutory delegation to noncongressional actors (courts) to develop antitrust policy. The problem is that the criteria do not begin to address the questions of degree that make the nondelegation question so difficult. Focusing just on the executive, there are legions of actions taken pursuant to statutes that affect private rights and that might be called general rulemaking. How are we to determine whether an individual example significantly affects private rights or thoroughly partakes of general rulemaking? Is the open-ended statutory instruction to the Federal Communications Commission to grant

${ }^{49}$ Id.; see also REDISH, supra note 11, at 101 ("In fashioning its definitions of branch power, the Court should look to a combination of policy, tradition, precedent, and linguistic analysis. Presumably, within certain linguistic boundaries, the definitions may evolve over time, much as the definitions of other constitutional terms have." (footnote omitted)).

${ }^{50}$ Calabresi, supra note 17 , at 1391-92.

51 See 15 U.S.C. $\$ 1$ (1994) ("Every contract, combination in the form of trust or otherwise, or conspiracy, in restraint of trade or commerce ... is declared to be illegal."). 
broadcast licenses if "public convenience, interest, or necessity will be served thereby" ${ }^{\$ 52}$ constitutional? Do the Environmental Protection Agency's flexible interpretations of the Clean Air Act significantly affect private rights, or thoroughly partake of general rulemaking? ${ }^{53}$

Calabresi presents the most well developed of the tests offered by commentators working in separation of powers scholarship. ${ }^{54}$ There is, of course, a substantial literature on the nondelegation doctrine, and I do not mean to repeat here the arguments contained in that literature. $^{55}$ But the fuzziness of the line between the legislative power and the other powers is the reason why some judges and many commentators accept the difficulty, if not impossibility, of court enforcement of a nondelegation rule. ${ }^{56 j}$ Analysis of Calabresi's test just serves as a reminder-rather than evidence to the contrary-that the line between legislation and execution is elusive.

Nor do commentators offer promising proposals to analyze the legislative boundary from the other angle. How are we to determine

5247 U.S.C. $\$ 307$ (a) (1994).

${ }^{53}$ See Jon Cannon, Bargaining, Politiss and Law in Environmental Regulation, in ENVIRONMENTAL CONTRACTS: COMPARATIVE APProACHES TO REGULATORY INNOVATION IN THE UNITED STATES AND EUROPE (Kurt Deketelaere \& Eric W. Orts eds., 2001) (commenting that the EPA has "considerable latitude to create and dispense flexibility").

${ }^{54}$ For Professor Redish, there must be "some meaningful level of normative political commitment by the enacting legislators, thus enabling the electorate to judge its representatives." REDISH, supra note 11 , at 136 . But, he observes, "[s] tatutes that ... amount[] to nothing more than a mandate to an executive agency to create policy" constitute unconstitutional delegations of legislative power. Id. at 137. For his part, Professor Lawson presents, in an admittedly preliminary analysis, an entirely circular definition: "Congress must make whatever policy decisions are sufficiently important to the statutory scheme at issue so that Congress must make them." Lawson, supra note 8, at 1239. Finally, Professor Currie observes that "Congress may not leave the fundamental policy decisions to others. This does not preclude Congress from leaving details to another agency, for filling gaps in applying inevitably imprecise legislation is inseparable from the executive function." Currie, supra note 9, at 28 (footnotes omitted).

55 For a recent sampling, see DAVID SCHOENBROD, POWER WITHOUT Responsibility: How Congress AbUSEs the People Through Delegation (1993), and Symposium, The Phoenix Rises Again: The Nondelegation Doctrine from Constitutional and Policy Perspectives, 20 CARdozo L. Rev. 731 (1999).

${ }_{56}$ As Abner Greene has commented:

The Court tried only twice to halt such . . . broad delegations before realizing that it was too difficult to draw a line between delegations that are unconstitutionally broad, because they give the executive something that looks like lawmaking power, and those that are sufficiently narrow, because they grant something that looks like enforcement discretion.

Greene, supra note 4, at 155 . 
whether legislative action improperly micromanages executive action? Most commentators do not even address the problem. Professor $\mathbf{R e}^{-}$ dish, to his credit, does, and he suggests that Congress goes too far when it "interfere[s] with the proper operation of another branch." That, however, is only the beginning of the inquiry, for one then needs to identify what it is to interfere with the proper operation of another branch.

$$
\text { * * * * }
$$

One might argue that the problem here is lack of effort. Perhaps we do not have a satisfactory way to tell the difference between government functions in close cases because insufficient attention has been devoted to the question. While there are a variety of additional ways one might try to define legislative, executive, and judicial power, we should not redirect our energies to these strategies because each is likely to fail.

One method that some in the current literature implicitly suggest as promising is the location of an authoritative baseline to guide definitional determinations. Under this method, a court would characterize a governmental activity by relying on some touchstone that would help determine whether a particular activity is legislative, executive, or judicial. ${ }^{58}$ The typical options for the baseline are history, tradition, or current practices. Consider the case of Bowsher $v$. Synar, where the activities of the comptroller general under the Gramm-RudmanHollings Act were at issue. ${ }^{59}$ The baseline approach would ask the following question: does what we know about the history (or tradition, or practice) of the three governmental powers suggest that the comptroller general's activities are executive, legislative, or judicial?

The baseline approach, however, is unlikely to escape the flaws with present approaches identified here. Investigation of the baseline may not yield clear enough answers to resolve specific cases. History, for instance, may show that the legislative power includes the power of

\footnotetext{
57 REDISH, supra note 11, at 120.

58 Calabresi and Prakash have described one such touchstone.
}

"[T] he executive Power," for example, is probably not so much a type of power as it is a grab bag of many specifically enumerated powers, all of which we think of as belonging to the Executive, either because they always did so belong in English and American history, or because the Constitution specifically assigns them to the President.

Calabresi \& Prakash, supra note 8, at 561 n.69.

478 U.S. 714,717 (1986). 
the purse, but it may tell us little about the more difficult questions such as what degree of spending discretion can be left to the executive ${ }^{60}$ If one relies on the history and tradition baselines, the outcome of the analysis is heavily dependent on the choice of the time frame. To ask only the most pointed question: Shall we determine the meaning of executive power before or after the New Deal? As for the current practices baseline, which attempts to take account of the government as it has evolved, it is vulnerable to the criticism that it mistakes what "is" for what "ought" to be. On the other hand, the history and tradition baselines are vulnerable to the opposite and familiar criticism: one might challenge the advisability of courts' use of original understanding, or tradition, to trump the consensus of the current, electorally accountable departments of government.

Aside from the location of an authoritative baseline, one might undertake a more explicitly instrumental or normative effort to define the boundaries among the powers. One version would be to study and evaluate the institutional structure of each of the departments of government. This, admittedly, would be a monumental task, but the objective would be to match the competencies of the institutions with the types of powers they exercise. ${ }^{61}$ Another approach, in the same vein, would be to focus on the normative purposes served by the particular power allocations. ${ }^{62}$ For example, the legislative power is vested in Congress because of the particular nature-a bicameral body with differing election cycles-of its electoral responsiveness, or the judi-

6ee Calabresi, supra note 17, at 1391 n.54 ("The power of the purse has been widely recognized to be a legislative prerogative in English and American history for many centuries. This, I believe, reflects a central reality about the core of what the phrase 'the legislative power' actually means and must mean."); see also SAIKRISHNA Prakash, The EsSential. MEaning of Executive Power (Univ. of S.D., Sch. of Law, Pub. Law and Legal Theory, Working Paper No. 04, Apr. 2000) (arguing at length that historical record reveals that executive power includes the power to execute the laws without addressing what executing the law means).

(1) See, e.g., N.W. Barber, Prelude to the Separation of Powers 1 (2000) (unpublished manuscript, on file with author) (arguing "that the essence of separation of powers is the meeting of form and function; the matching of tasks to those bodies best suited to execute them").

${ }^{62}$ David Currie argues that:

Article I of the Constitution entrusts the legislative power of the United States to the Congress, so that democratically elected representatives will determine national policy. Article II vests the executive power in the President, in the interest of unified administration by an elected officer. Article III places the judicial power in judges appointed for life and removable only for high crimes and misdemeanors, so that cases may be decided without fear of reprisal.

Currie, supra note 9 , at 19. 
cial power is vested in the judiciary because its decisionmakers have protections that assure their independence-lifetime tenure and salary. Following this approach, the objective would be to line up the power allocation with the reason for the allocation.

These efforts are more promising than some others evaluated here because, rather than abstractly attempting to define government functions, they would allocate the functions based on the reasons why we might want particular kinds of government authority exercised by differently designed institutions in the first place. Even if more developed, however, these approaches predictably will fall short. Faith that we could settle on the comparative institutional competencies of the branches of government seems naive because it aspires to develop some objective measure of the competency of a branch; but any such effort would be inevitably intertwined with normative judgments about which institution should exercise a certain kind of government authority. Normative disagreements about those matters would not vanish due to supposed evidence that one branch or another is more "competent" to perform a particular task. Trying to assign specific exercises of government authority based on the general normative reason for the power allocation-for instance, Congress decides certain questions because of its particular electoral responsiveness-would also be likely to fail in any particular case just as the vague efforts at defining the nondelegation line fail.

These broad-brush efforts to match the institutional competency or normative suitability of a "branch" with the exercise of a particular power are destined to fail for a more fundamental reason. As the next section will argue, the branches are complex entities with many different subparts. Given that reality, it would be an impossible endeavor to identify $a$ branch's institutional competency or suitability writ large.

$$
* \quad * \quad *
$$

Given that we now have no satisfactory definitions of the three functions of government-and little prospect of developing themcurrent approaches are misdirected. ${ }^{63}$ The debate in the courts and

${ }^{63}$ This Article is not alone in challenging conventional approaches to separation of powers. A group of commentators, one might even call them a revisionist school, are critical of separation of powers orthodoxy. See supra note 13 (citing sources). Some in this group explicitly criticize the traditional emphasis on the identification and separation of the three governmental powers. They argue that such a focus invites a question-begging analysis, see Merrill, supra note 6 , at 245 , and fails to capture important values underlying the horizontal constitutional structure, see Nourse, supra note 
much of the literature proceeds on the assumption that, in at least some range of cases, there is a way to classify government authority into three categories and assure that the functions are exercised by distinct institutions. But we have no such method now and, given the options, it makes no sense to reorient our energies to developing evermore-refined ways to classify government authority into one of three categories. Spending time trying to characterize government authority is just asking the wrong question. The focus of our discussions should be on conceptualizing separation of powers doctrine in a way that does not depend so heavily on distinctions among the three governmental functions. Rather than there being a few such efforts, our law reviews should be filled with them.

\section{B. Three Balanced Branches}

Current thinking about separation of powers is also committed to some particular allocation of government power among three branches, or, to put the commitment more colloquially, the preservation of three roughly "balanced" branches of government. ${ }^{64}$ This idea is articulated in a variety of ways: maintaining a balance among coequal departments; ${ }^{65}$ or preventing encroachment or aggrandizement of one department at the expense of another. ${ }^{66}$ Concern that a par-

13, at 751-52. To be sure, none in this revisionist school argue in a sustained way that we lack a satisfactory method to identify the differences among the three powers. The critique offered here is thus distinct from these other efforts, as is the proposal offered in Part II, but this Article should be read as a complement to them.

${ }^{64}$ Because of its association with a contextual, standard-like approach to deciding particular cases that come before courts, balance is a word that many formalist commentators eschew. See, e.g., REDISH, supra note 11, at 125. This section is consistent with the formalist's critique of a balance-between-the-branches analysis used to decide individual cases. But the argument here goes beyond the disutility of using such a standard to decide cases. The critique in this Part is of the basic idea that there must or can be rough balance among branches of government. This idea operates at a higher level of abstraction than the decision rules for individual cases and, at that level at least, it is an idea to which every party in the debate adheres. The disagreement about how best to implement that idea in particular cases is a separate question. Regardless of how one wishes to implement it in individual cases, the argument of this section is that the concept is too problematic to be a useful tool of analysis.

${ }^{65}$ For academic references, see Calabresi \& Rhodes, supra note 8, at 1216; Cynthia R. Farina, Statutony Interpretation and the Balance of Power in the Administrative State, 89 COLUM. L. REV. 452, 488-99 (1989); Flaherty, supra note 5, at 1810-21; Froomkin, supra note 4, at 1374-75; Greene, supra note 4, at 138; Miller, supra note 9, at 54; Strauss, supra note 12, at 522. For judicial references, see Clinton v. City of New York, 524 U.S. 417, 452 (1998) (Kennedy, J., concurring), Mistretta v. United States, 488 U.S. 361, 412 (1989), and Morrison v. Olson, 487 U.S. 654, 699 (1988) (Scalia, J., dissenting).

${ }^{66}$ See, e.g., Froomkin, supra note 4, at 1368 ("Overall, the Court's decisions fit a 
ticular arrangement may upset the proper balance among the branches surfaces in a variety of contexts, including the growth of the administrative state ${ }^{67}$ the legislative ${ }^{68}$ and line-item vetoes, ${ }^{69}$ the independent counsel, ${ }^{71}$ and other appointments arrangements." Commitment to the idea of balance arises from an understanding of the architecture that the Constitution establishes. The idea is that, if the functions of government are exercised by three different institutions and the checks by one institution as against the others are maintained, that arrangement is appealing because it produces three potent institutions that share in the exercise of government power. Unfortunately, the notion of balance is both conceptually underdeveloped and flawed. This section first clarifies the idea and then raises a series of objections to it.

pattern in which Congress's power to check the other branches by determining their structure is very great, but Congress is checked by the requirements that it act through persons outside the legislature ... and that Congress not aggrandize its own powers."); Greene, supra note 4, at 158-77 (analyzing various arrangements of congressional and executive powers through the prism of the anti-aggrandizement principle). The Supreme Court has frequently observed that the structural provisions of the Constitution are intended to prevent encroachment or aggrandizement of one branch at the expense of another. Clinton, 524 U.S. at 482; Metro. Wash. Airports Auth. v. Citizens for the Abatement of Aircraft Noise, Inc., 501 U.S. 252, 273 (1991); Mistretta, 488 U.S. at 382; Morrison, 487 U.S. at 693; Commodity Futures Trading Comm'n v. Schor, 478 U.S. 833, 850 (1986); Bowsher v. Synar, 478 U.S. 714, 727 (1986); Buckley v. Valeo, 424 U.S. $1,122(1976)$.

67 See Flaherty, supra note 5, at 1820-21 (examining the implications on the powers of Congress and the President following the "death of the nondelegation doctrine"); Greene, supra note 4, at 158-62 (discussing congressional efforts to secure a role in the appointment of executive officials in a "post-nondelegation doctrine world" where "the presidency has become bloated with legislative power").

${ }^{68}$ Froomkin, supra note 4, at 1368; Greene, supra note 4, at 165.

69 Clinton, 524 U.S. at 451-52 (Kennedy, J., concurring); Powell \& Rubenfeld, supra note 3, at 1196; Glen O. Robinson, Public Choice Speculations on the liem Veto, 74 VA. L. REV. 403, 406-07 (1988); Maxwell L. Stearns, The Public Choice Case Against the Item Veto, 49 WASH. \& LEE L. REV. 385, 390 (1992). But see Neal E. Devins, In Search of the Lost Chord: Reflections on the 1996 Item Veto Act, 47 CASE W. RES. L. REV. 1605, 1624-25 (1997) (claiming that "Congress can easily blunt" the legislative power transferred to the President).

${ }^{70}$ Steven G. Calabresi, Some Siructural Consequences of the Increased Use of Ethics Probes as Political Weapons, 11 J.L. \& POL. 521, 522 (1995).

${ }^{71}$ See Froomkin, supra note 4, at 1368 (asserting that Congress violated the separation of powers by reserving a role in the removal of the postmaster general and comptroller general); Greene, supra note 4, at 16465 (arguing that congressional power to remove the comptroller general, who played a role in the Gramm-Rudman-Hollings deficit-reduction scheme, meant that Congress had improperly aggrandized its own powers). 
The first point to be clarified is the relationship between maintaining rough balance among the departments and assuring the institutionally separate exercise of the three government functions. On one understanding, balance among the departments bears a direct relation to functional separation: in order to guarantee the dispersal of government functions among three institutions, each institution must be able to protect the exercise of its function, and it is for that reason that the branches need to be balanced. ${ }^{72}$ This explanation, however, is partial; it suggests that our commitment to three potent government institutions is solely aimed at the preservation of the separate exercise of the functions of government. We are committed to balance, however, even where the possible misallocation of the three functions of government is not at stake. ${ }^{73}$ The reason for providing the President with a veto illustrates the point most easily. If the sole reason we want the branches to remain roughly balanced is to preserve the dispersal of three government functions in different institutions, then the only reason the President has the veto is to reject bills that alter the allocation of functions among the departments-those that purport to strip the President of some executive power, or permit Congress to exercise judicial power. But the President's veto authority is understood, at least today, to enable the President to veto bills based on policy differences with the Congress, not simply claims of unconstitutional redistribution of the underlying functions of government. $^{74}$ Thus, maintaining balance among the departments is

72

See Magill, supra note 6, at 1149 (arguing that conventional approaches to separation of powers treat the checks as a way to permit the branches to "protect the exercise of their own functions and check the exercise of functions by the others").

${ }^{73}$ See Nourse, supra note 13, at 760-68 (discussing the ways in which balance would be dramatically altered by changes in institutional design that do not involve any change in function).

${ }^{74}$ The distinction between use of the veto to prevent unconstitutional action and use to express policy difference was familiar at the Founding. JACK N. RAKOvE, Original Meanings: POlitics and IdeAs In the Making OF THE Constitution 26162, 267-68 (1996) (identifying a distinction in the Philadelphia Convention debates between the ability of the executive to resist legislative encroachments such as efforts to strip the President of the veto authority, and the ability of the executive to prevent the adoption of unjust legislation); see also DAVID P. CURRIE, THE CONSTITUTION IN CONGRESS: THE FEDERALIST PERIOD, 1789-1801, at 31-32 (1997) (questioning the claim that President Washington viewed exercise of veto power as appropriate only on constitutional grounds, and asserting that, if Washington ever held that view, he had abandoned it late in his Presidency when he vetoed a bill on policy grounds); THE FEDERALIST No. 73, at 443 (Alexander Hamilton) (Clinton Rossiter ed., 1961) ("[The veto] not only serves as a shield to the executive, but it furnishes an additional security 
about something more than preserving the allocation of government functions.

But just what is that something more? Why should we care about balance among the branches? Oddly enough, current thinking rarely addresses that question. Discussions of the need to prevent aggrandizement or to preserve balance among the departments assume that balance among the three branches is an end in itself. Consider a world in which the President does not have the power to veto bills. This arrangement, according to the conventional formulation, would create a dangerous imbalance of power among the branches by aggrandizing Congress at the expense of the President. This conclusion implies that we care about the weakening of the Presidency for its own sake. ${ }^{75}$

The key to understanding concerns about aggrandizement and the preservation of balance is to notice when we would not care about it. To risk stating the obvious, we would not be concerned about the balance of authority among the branches if there were no salient differences among them. That is, if we were absolutely certain that no matter which branch-or combination of branches-made a decision, and the conclusion reached would be the same, ${ }^{76}$ then there would be

against the enaction of improper laws."). Whatever the historical understanding about the appropriate use of the veto, there is no question that today it is understood to permit the expression of policy difference. See CHARLES M. Cameron, Veto Bargaining: Presidents and the Politics of Negative Power 33-68 (2000) (presenting empirical evidence indicating that the veto power has been used primarily to express policy difference); Louis Fisher, THE Politics OF SHAREd POWER: CoNGress AND THE EXECUTIVE 28-32 (4th ed. 1998) (discussing the role of the veto in asserting policy difference).

Commentators have noticed the Supreme Court's tendency to engage in this sort of analysis. See Brown, supra note 13, at 1518 (“[J] udicial opinions addressing the separation of powers ... tend to place primary emphasis not on the prevention of tyranny or protection of individual liberties, but on the advancement of the institutional interests of the branches themselves, as if that goal were itself a good-a proposition with no historical support." (footnote omitted)); Lessig \& Sunstein, supra note 8, at 115 (asserting that Supreme Court caselaw reflects a distinction between improper congressional aggrandizement over administrative agencies and proper protection of those agencies' independence, but lamenting that the Court's explanation of this distinction "sometimes reads like a kind of 'turf protection' model").

${ }^{76}$ I focus here on expected differences in outcome produced by an institutional arrangement because that is the best way to understand the cases where claims about aggrandizement or balance are made. One might make claims about balance or aggrandizement with respect to what are regarded as an analytically distinct set of concerns about the normative suitability (Congress should make a certain set of decisions because of its particular electoral accountability, or electorally insulated judges should decide disputes between individuals as to the meaning of law) or institutional competency (the President as a single head of state is most suited to take a dominant role in 
little reason to be concerned about the allocation of decisionmaking authority among them. To take one example, if we knew that the President's ability to exercise the veto had no effect whatsoever, we would not care if the President no longer had the veto. The commitment to rough balance among the branches is thus best understood as based on the assumption that actors in different parts of government will not decide questions in the same way, that there will be some systematic differences in their decisionmaking. ${ }^{77}$

It is worth observing that an assumption that the branches will reach systematically different outcomes is open to challenge. Behavioralist literature, now out of vogue in the wake of the so-called "new institutionalism," asserts that people and their ideology matter most, and that people of similar ideologies will systematically reach the same outcomes regardless of their institutional placement. ${ }^{78}$ The debate about whether Article III courts act in a countermajoritarian fashion can also be understood in this context. Advocates of the claim that the Supreme Court rarely acts in a countermajoritarian way are of the view that the Court does not make dramatically different decisions than the electorally accountable branches of government. ${ }^{7 !}$

Concern that an arrangement will aggrandize one branch at the expense of another implicitly rejects the idea that the institutions of the national government are interchangeable. Instead, as just observed, worries about balance are rooted in the intuition that the branches are importantly different and that is why the distribution of

\footnotetext{
foreign relations) of the branches to perform certain tasks. Such concerns are conventionally thought to have significance independent of outcome. Whether these concerns operate entirely independently of expected outcome differences, the point here is that, while these concerns could be invoked in terms of aggrandizement or balance, they usually travel under claims about the mixing of functions, the commitment analyzed in Part I.A. Thus, for example, adjudication of individualized disputes by administrative agencies might be understood as aggrandizement of the executive branchand, if so, the understanding of aggrandizement contained in the text is too narrowbut the debate is instead about the dangers of altering the functional allocation, that is, of executive-branch judges adjudicating federal-law disputes and thereby inappropriately exercising the judicial power.

I take this to be the central insight of Victoria Nourse's piece, Vertical Separation, supra note 13. See id. at 792 ("Vertical analysis ... assumes that the departments are different because they represent different constituencies.").

${ }^{78}$ For an abbreviated summary of behavioralist approaches, see Keith E. Whittington, Once More unto the Breach: PostBehavioralist Approaches to Judicial Politics, 25 LAW \& SOC. INQUIRY 601, 604-07 (2000).

${ }^{79}$ See generally Gerald N. Rosenberg, THE Hollow HoPe: CaN COURTS Bring ABOUT SOCIAL CHANGE? 338 (1991); Michael J. Klarman, Rethinking the Civil Rights and Civil Liberties Revolutions, 82 VA. L. REV. 1, 6 (1996).
} 
authority among them matters. Return to the example of the presidential veto. The argument for the existence of the veto-that its existence "balances" the power of Congress-assumes that Congress and the President together will reach a different set of outcomes than Congress by itself would reach, and of course that the distinctive effect that the President's involvement adds to decisions is valuable. Understood in this way, balance or policing aggrandizement are not metaphysical commitments to three institutions in equipoise, but rather are about protecting a particular allocation of decisionmaking authority among departments that will decide questions differently.

The branches will decide questions differently only if the incentives of the actors in the three branches are systematically different. This operating assumption is usually unstated and, consequently, its contours are undeveloped; the literature does not usually contain a description of the different incentives or a demonstration that they exist. ${ }^{80}$ I will argue soon that an effort to demonstrate the existence of systematically different incentives or, what is more important, to predict the consequence of any such differences, is likely to fail given the monumental complexity of the task. For the moment, however, notice the nature of the assumption. Intuitions about salient interbranch differences must be rooted in the distinct organization of, and relationship among, the institutions-decisionmakers with varying electoral and tenure regimes who are charged with the exercise of a distinct mix of governmental functions. Consider the example of the line-item veto. One common claim is that the line-item veto aggrandizes the President. ${ }^{81}$ This claim has two parts: the line-item veto will

${ }^{80}$ A few commentators recently have begun to focus explicitly on the incentives of the actors in the different branches. See Steven G. Calabresi, Some Normative Arguments for the Unitary Executive, 48 ARK. L. REV. 23, 34-35 (1995) (describing the President as a safeguard against "the bad distributional incentives" of Congress); Fitzgerald, supra note 13, at 753 (noting that Congress's constituency is local or statewide in character, while the President's "is national in both scope and in character"); Nourse, supra note 13, at 758 ("Any complete understanding of shifting power must grapple with the political incentives that constitutive power creates.").

${ }^{81}$ See Calvin Bellamy, Item Veto: Shield Against Deficits or Weapon of Presidential Power?, 22 VAL. U. L. REV. 557, 581-87 (1988) (concluding that the item veto expands the legislative powers of the President by allowing him to implement his own spending agenda); Powell \& Rubenfeld, supra note 3, at 1196 (noting the argument that "the Line Item Veto Act gives the President the power to rewrite legislation" and thus violates the general principle of separation of powers); Robinson, supra note 69 , at 413 (noting that "almost everyone sees the item veto as the source of increased executive power"); Stearns, supra note 69 , at 401 ("[T] he item veto would rework a fundamental shift in the balance of power, providing the President with powerful opportunities to influence the direction and shape of legislative priorities, while affording him surpris- 
change outcomes; and those outcome differences are to be lamented. The outcomes would be different because the President and the Congress would have systematically different reactions to spending and tax choices. Any such systematic differences would have to spring from a complicated set of internal and external factors, including the type of individuals who populate the executive branch and the Congress, the internal norms of those bodies, and the different constituencies that influence them. Discussions of the line-item veto tend to focus only on the last of these factors; allegedly, certain constituencies will have more sway with the President than with Congress, and others will have more sway with Congress than with the President. The putative variation in the responsiveness to constituencies relevant to the line-item veto runs as follows: the President will care more about national constituencies and less about localized constituencies than the Congress will. $^{82}$ Hence, the President will not veto an item that has the strong support of a national constituency, but may veto provisions that a localized constituency was able to persuade a minimum-winning coalition in Congress to support. And why should that outcome difference be lamented? Those opposed to the veto do not want the executive interest to prevail more often than it would without the veto; more concretely, they do not want the national constituencies with more influence with the President to be advantaged and the more localized constituencies with more influence with the Congress to be disadvantaged.

$$
* \quad * \quad *
$$

Understanding claims about balance and aggrandizement in this way helpfully redirects attention away from abstract notions about keeping the three institutions magically balanced for their own sake. The redirection, however, does not transform these ideas into useful tools of analysis. On the contrary, it is a hopeless enterprise to talk about the balance or imbalance among the branches of government, and it is one that should be abandoned.

If balance among the branches should be understood to be about the appropriate distribution of government decisionmaking authority

\footnotetext{
ingly little opportunity to excise the dreaded pork.").

${ }^{82}$ See Calabresi, supra note 80, at 78-79 (comparing the local incentives of Congress with the "national, anti-factional" concerns of the President); Robinson, supra note 69, at 411 ("The intuition may be that because of the President's nationwide constituency he is held specially accountable for the fate of general enactments ....").
} 
among institutions that have different ways of making decisions, what is the proper distribution? How we could or should answer this question is left entirely undeveloped in conventional accounts. Answering this question requires at least three levels of analysis, each one vexing in its own right. We would need a benchmark of the appropriate distribution of authority among the branches that could be used to determine whether a change in their relationship to one another is impermissible; we would need a way to define, measure, and compare government power across institutions exercising different types of authority; and finally, we would need the ability to understand and predict the way in which a new institutional arrangement would alter the relationship between the branches. Consider again the line-item veto. To decide whether that device would inappropriately empower the President at the expense of the Congress, we would need to predict whether and how the existence of the veto would affect the relationship between those branches. We would then need to determine whether any change violated an agreed-upon benchmark of the proper distribution of authority among the institutions. Answering that question would require both that we settle on such a benchmark, and also that we be able to evaluate the comparative power of the institutions. We are not now equipped to answer these questions, and we never will be.

Before further examining the difficulties with the idea of balance, however, it is worth noting that the aggrandizement inquiry does not avoid these questions. At first blush, it appears more helpful than the balancing formulation because there seems to be no need to measure the quantum of power held by different institutions or to settle on a benchmark of proper allocation that could be used in assessing each arrangement. One just has to be able to detect whether one of the branches will be empowered-in the sense that it will have an improved ability to affect outcomes ${ }^{83}$-by the arrangement. In fact, however, the aggrandizement inquiry does take a stand on the appropriate allocation of authority among the branches, and obviously so. Aggrandizement is only a meaningful concept when it can be compared to a baseline. And the usual formulation (consistent with the connotation of the word used) is that a device that aggrandizes a branch is invalid. But to say that aggrandizement is disfavored is just to say that the previous baseline is preferable. The reason for always

${ }^{83}$ As I soon make clear, deciding whether a branch is empowered is a tricky question. Infra notes 88-97 and accompanying text. For now, please accept this working definition. 
preferring that baseline should be defended, but it cannot be. The allocation of authority among the branches is not static, but fluid, ${ }^{84}$ and at any point in time there is no reason systematically to prefer the status quo ante of authority. Once we step away from an antiaggrandizement rule that always defends the existing allocation of authority, however, we need to decide whether an arrangement that aggrandizes one department is desirable. That question, however, just returns us to the basic difficulties of the balancing formulation.

Critics who invoke the ideas of balance or aggrandizement do not supply helpful frameworks for answering any of these questions. Recall that there are three questions that must be considered: normatively, what is the proper distribution of authority among the branches; descriptively, what is the distribution of authority among the branches at a particular point in time; and predictively, how will a particular institutional arrangement alter the relationship among those branches?

By itself, the normative question might stop us in our tracks. We are unlikely ever to reach agreement on some ideal distribution of authority among the branches. Even if we narrowed the question considerably-for instance, should the Congress or the executive have the dominant role in controlling the domestic economy during times of economic dislocation?-it does not seem likely that we could soon reach a consensus. Still, it might be worth the effort to develop such a baseline if we could answer the other two questions. If we had a way to discern the distribution of authority at any point in time, and a way to predict the effect of particular arrangements, then articulating an appropriate distribution of authority might be a worthy endeavor. But the surprising news is that, even if we reached agreement on the nor-

\footnotetext{
${ }^{8.4}$ Although there is no agreement on the shape of the fluidity, no one seems to think that the allocation of authority among the branches remains stable across time. Calabresi, supra note 80 , at 33-39; Froomkin, supra note 4 , at 1375 . Some argue that, in this century, the executive has become excessively powerful in relation to the other branches of government. See Flaherty, supra note 5, at 1816-21 (documenting the rise of the executive branch's power relative to Congress); Greene, supra note 4, at 134 (noting "the simple and incontestable fact that the post-New Deal presidency has substantially greater policy-making power than the pre-New Deal presidency, both in absolute terms and relative to Congress"). Others argue that the executive has been relatively weakened because of limitations on the President's ability to control those nominally in the executive branch. See Calabresi, supra note 80, at 31-33 (noting the argument that "Congress has used its power to structure the cabinet departments and agencies in ways that make it very difficult for the President to oversee and control them, most especially by making certain officers independent and removable only 'for cause"").
} 
mative question, the other two questions still would be unanswerable.

Examine first the need to discern the quantum of power held by an institution and to compare it to the amount of power held by other institutions: Claims that an arrangement will-or will not-increase the power of one branch at the expense of another are common in separation of powers cases and commentary. ${ }^{85}$ One set of critics, for instance, maintains that the executive branch has accumulated excessive power. ${ }^{86}$ These critics argue that contested constitutional arrangements like the legislative veto, line-item veto, and appointments regimes must be viewed through the prism of a now-dominant executive branch. ${ }^{87}$ But these accounts rely on the concepts of imbalance and aggrandizement without identifying what they mean.

Consider the most developed of the arguments in this vein. Professor Martin Flaherty argues that we have shifted from congressional government to presidential government, with the executive, instead of Congress, dominating the scene. He points to important changes over time in a variety of areas: presidential control of law enforcement, dominance in foreign affairs, and energetic initiation of legislative proposals. ${ }^{88}$ But for Flaherty, and for oth-

${ }^{85}$ See, e.g., Bowsher v. Synar, 478 U.S. 714, 727 (1986) ("The dangers of congressional usurpation of Executive Branch functions have long been recognized."); INS v. Chadha, 462 U.S. 919, 958 (1983) ("[T] he carefully defined limits on the power of each Branch must not be eroded."); Froomkin, supra note 4, at 1368-69 (explaining separation of powers cases as permitting appropriate congressional regulation of the executive in order to respond to the growth of presidential power, but not permitting such regulation if it aggrandizes Congress, because that would lead to too much congressional power); Greene, supra note 4, at 158-77 (same).

${ }^{80}$ See, e.g., William N. Eskridge, Jr. \& John Ferejohn, The Article I, Section 7 Game, 80 GEO. L.J. 523, 533 (1992) ("[The] shift to agency lawmaking has been accompanied by an overall shift of lawmaking authority from Congress to the President."); Flaherty, supra note 5, at 1821 ("[E]ven the most glancing survey indicates that the executive branch long ago supplanted its legislative counterpart as the most powerful-and therefore most dangerous-in the sense that the Founders meant."); Froomkin, supra note 4, at 1375 (noting that although some authors disagree, he, and others, "continue to see an imperial Presidency"); Greene, supra note 4, at 153-55 (noting the expansion of presidential power in the post-nondelegation era).

${ }^{k 7}$ See Flaherty, supra note 5, at 1832-39 (criticizing "the Court's historically novel forays into separation of powers" and emphasizing that "[f]rom the perspective of changed circumstances...the outcome of those sallies has been even worse"); Greene, supra note 4, at 154 ("[W]e must evaluate twentieth-century congressional framework legislation in light of the great twentieth-century giveaway of legislative power... [F] or the essential balance of powers to be maintained, the President himself must now be checked."); see also Eskridge \& Ferejohn, supra note 86, at 533 ("If the Court is truly serious about the Framers' original expectations ... the Court should be more attentive to the ways in which agency lawmaking unsettles those expectations.").

${ }_{88}$ Flaherty, supra note 5, at 1817-19. 
$\mathrm{ers}^{89}$ the most obvious shift toward presidential power, and away from Congress, has been the creation and judicial acceptance of the administrative state. As Flaherty observes:

With the New Deal, and the attendant death of the nondelegation doctrine, the giveaway of what had been seen as legislative authority (or something close) became massive.... At least as important as the scope of modern delegation, however, is to whom the power has been delegated. If there has been any net beneficiary of Congress's abdication of authority, it has been the President.... [A] substantial measure of power that under the nondelegation doctrine would by definition have resided in Congress has since fallen to the President. ${ }^{90}$

For Flaherty and others, ${ }^{91}$ doctrinal prescriptions arise out of this shift in power from Congress to the executive. At a minimum, Flaherty maintains, Congress must be permitted "to maintain some control over the authority the Court now permits it to delegate away to the administrative state." ${ }^{92}$

Flaherty provides no explanation of how he measures the power of a branch of government, much less how he makes comparative assessments between the executive and the legislature. Examine first the claim that the executive is more powerful than it used to be. Of course, the executive has grown; it does more things than it used to; the nature of the Presidency has changed. But this falls short of demonstrating that the executive is more powerful than it used to be; the relevant question is about the relative power of the executive. ${ }^{93}$ Flaherty does not examine external factors, even though doing so is necessary to understanding the relative power of the President. At a minimum, one must understand the President in relation to other governmental actors, including the other branches of the federal government, and the relationship between the executive and state gov-

${ }^{89}$ Eskridge \& Ferejohn, supra note 86, at 533; Greene, supra note 4, at 154.

${ }^{90}$ Flaherty, supra note 5, at 1820-21.

${ }^{91}$ See Eskridge \& Ferejohn, supra note 86, at 534-47 (analyzing the three ways Congress has attempted to offset pro-President bias in agency lawmaking: "the legislative veto of agency rulemaking, delegation of responsibilities to congressionallydominated agents, and procedural checks on agency rulemaking"); Greene, supra note 4, at 171-77 (discussing Congress's Court-approved ability to "regulate the removal of agency personnel, to ensure that the President does not control all the power delegated away from Congress").

${ }^{92}$ Flaherty, supra note 5, at 1821.

${ }^{93}$ For rich description and nuanced analysis of the factors that help shape presidential power, see Charles O. JONES, THE PRESIdENCY IN A SEPARATED SYSTEM (1994); and Richard E. Neustadt, Presidential Power and the Modern Presidents: The POLITICS OF LEADERSHIP FROM ROOSEVELT TO REAGAN (1990). 
ernments. In addition, nongovernmental factors such as economic, social, and international developments also affect the relative power of the President. ${ }^{94}$ If one could take account of all these factors, perhaps the executive has the same relative power that it used to have, even though that power, when considered in isolation, has grown.

The need for a more refined definition of power is even clearer when one focuses on the claims that one branch of the national government is more powerful than another. One common assumption behind these claims is that government power is a zero-sum product: if the power meter registers an increase in the executive branch, it at the same time registers a decrease in the legislative branch. ${ }^{95}$ But that cannot be right. Arrangements could weaken, or strengthen, different branches at the same time. One might say that the office of the independent counsel weakened both the President and Congress by heightening voters' dislike for politicians. ${ }^{96}$ The prime example that Flaherty and others rely on, the growth of the administrative state, provides the best example of the error of the zero-sum assumption. The creation of the administrative state has increased the overall authority of the federal government, to the benefit of both the President and the Congress.

Even accepting that the President and Congress have both benefited from the creation of administrative agencies, one might still claim, as Flaherty does, that the President is the "net beneficiary" of this development. ${ }^{97}$ Notice at the outset that the claim is counterintuitive. It asserts that Congress densely gave away its power to the executive without an equivalent benefit to itself. But this has to be a mis-

94 See JONEs, supra note 93, at 282-83 (concluding that the "substantial differences in the personal and political background of presidents and how they come to serve in the White House ... can lead to strategies ... that aid in explaining performance in office"); NEUSTADT, supra note 93, at 3-9, 183-229 (discussing various social, economic, and international factors that had bearings on the demonstration of power by modern Presidents).

${ }^{95}$ Flaherty, supra note 5, at 1819-21 (stating that with the decline of the nondelegation doctrine the President has become the "net beneficiary of Congress's abdication of authority"); Greene, supra note 4, at 154-55 (arguing that if Congress begins to delegate its broad legislative powers to the executive branch, then the President must be checked to maintain the balance of powers); see also Eskridge \& Ferejohn, supra note 86 , at 533 (noting that the "shift to agency lawmaking has been accompanied by an overall shift of lawmaking authority from Congress to the President").

${ }^{96}$ See Calabresi, supra note 80 , at 93-94 (noting that the existence of the Independent Counsel inevitably leads to more frequent and politicized investigations, which "encourages an excessive distrust of the government and of government officials, and it prevents government from addressing the real problems of the nation").

${ }^{97}$ Flaherty, supra note 5, at 1819, 1821. 
taken understanding of why Congress delegates; the ability to delegate provides many advantages to Congress. ${ }^{98}$ How we could discern that the President got the best of the bargain is unknown. The claim assumes the existence of an imagined tool that can identify which branch is more powerful. But what that tool measures, and how it does so, is left unstated. One potential understanding of this instrument is that it simply measures how often one branch prevails over another, which is probably the best approximation of what commentators mean when they rely on the sorts of claims evaluated here. More precisely, claims that one branch has been aggrandized or weakened in comparison to another seem implicitly to assume that the ability of the institution to achieve its preferred outcomes when the branches are pitted against one another is the appropriate measure of the balance of power between them. If this is a correct understanding of what courts and commentators implicitly mean when they argue that one branch has been strengthened in relation to another, it is worth noting that none of those invoking these ideas demonstrate that one branch or another has achieved its preferred outcomes more often. For instance, while Professor Flaherty argues that the executive has become the "most dangerous branch," he does not demonstrate that the outcomes preferred by the executive prevail over outcomes preferred by the legislature more often than they used to, much less the further claim that the executive prevails more often than it should. 9

Measuring the changing frequency of branch victories is one way to measure the comparative power of institutions, and it is the measure I will examine hereafter. But at the outset, notice that this way of measuring inter-institutional power is limited. This method assumes that the salient time one should measure the power of the branches is when they are in some sort of conflict. It is only then that one can see that two institutions have different preferred outcomes, and that one or the other has prevailed. Presumably, conflict means those highprofile moments with which we are familiar: judicial determinations whether a statute is constitutional; battles over vetoes and overrides; nomination or treaty fights; and impeachment controversies. But

${ }^{98}$ See D. RODERICK KIEWIET \& MATHEW D. MCCubBINS, THE Locic OF Delegation: Congressional Parties and The Appropriations Process 167-85 (1991) (rejecting the "abdication hypothesis" and arguing, through study of legislative delegation of budgeting authority to the President, that Congress delegates to the executive in order to better achieve its own policy objectives); Peter H. Aranson et al., $A$ Theory of Legislative Delegation, 68 CORNEL.L L. REV. 1, 37-62 (1982) (describing how delegation by Congress can facilitate the collective provision of private goods).

Flaherty, supra note 5. 
what if we are in a period where no such conflict exists among the branches? Under this way of measuring power, there are no data points to count. But the lack of such conflicts could mean that one branch is so dominant that neither of the other branches is willing to challenge it in any way.

Counting only these high-profile conflicts may also miss other important parts of the picture. If the President's veto is sustained three out of four times, does that mean that the President is more powerful than the Congress? What if, in the same period when the President's vetoes are largely sustained, the executive's efforts to initiate or shape legislative proposals are dead letters in Congress? The executive's failure is relevant to the relationship between the President and legislature, but the developments are unlikely to produce a neatly measurable outcome. Moreover, attaching significance to these high-profile

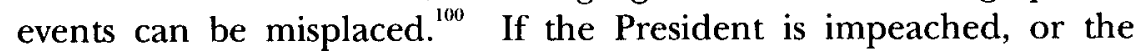
President's Supreme Court nominee is rejected, does either event mean anything systematic about the balance of power between the two branches? The impeachment may mean something about a particular President, and the rejection of the nominee may mean something about judicial politics at a point in time, but they may not tell us anything generalizable about the relationship between those institutions. Finally, it seems unlikely that these data points, as crude as they are, would easily yield an answer about which branch is more powerful. Imagine that the President wins three out of four veto overrides in a certain period. At the same time, Congress is conducting an investigation into corruption in parts of the executive branch, and the resulting disclosures lead to the resignation of senior officials in several departments, thus hampering the President's effort to launch a major initiative. During the same period, too, three out of four of the executive's efforts to interpret important statutes-through rulemaking-have been invalidated in the courts. Even this unrealistically simple example-in terms of the events worth counting-suggests that evaluating that data would be an impossible task.

Despite the many inadequacies of this measure, assume that the best way to measure the comparative power of institutions is to discern how often the outcomes preferred by one of them occur. Having settled for the moment on a way to measure the comparative power of

${ }^{100}$ See Rebecca K.C. Hersman, Friends and Foes: How Concress and the PRESIDENT REALly MAKE FOREIGN POLICY 3-9 (2000) (arguing that an emphasis on high-profile events in congressional/executive relations in the area of foreign policy gives a distorted picture of those relations). 
the branches of government, we have a working answer for one of those vexing questions. Even so, relying on this measure to evaluate institutional arrangements is problematic. There is, of course, the lurking and daunting normative question about what the distribution of authority should be. But there is a difficulty independent of this; we cannot predict with any confidence whether outcomes will be changed as the result of a new arrangement.

An extreme case illustrates the prediction problem. Consider the following arrangement, where it seems easy to claim that some outcome difference will result: freeing the President of the need to gain the Senate's approval for treaties and nominations. Given that the President would no longer have to care about the views of the Senate in these contexts, the arrangement would "aggrandize" the President at the expense of the Senate. Recall that this concern about aggrandizement has two parts: the prediction that the President's new-found freedom from Senate approval would mean that he would enter into treaties and make nominations that he otherwise would not; and the judgment that such an outcome difference would be regrettable. Surely, this is a case where the first of these claims, that outcomes would be changed, is correct.

Even this supposedly easy case is tricky. Whether outcomes change as a result of freeing the President of this requirement depends on two factors: the significance one ascribes to the rule requiring advice and consent; and the existence of systematically different preferences between the President and the Senate. Ascribing great significance to the rule risks exaggerating its effect. It may be that the President would take account of the Senate's views even if the Senate did not formally have the authority to reject nominees and treaties. ${ }^{101}$ This is because there are other features of the relationship between the Senate and the President that would provide the President with the incentive to care about the views of the Senate. Even if the Senate did not retain its advice and consent function, the Senate's approval would be necessary for legislation, the Senate would participate in veto overrides, and, more remotely, the Senate would have a role to play in impeachment. Given that the Senate would have the power through these mechanisms to retaliate against the President for a treaty or nomination that the Senate collectively strongly opposed, the President might take account of the Senate's views even without the

${ }^{101}$ Cf. Louis Fisher, Constitutional Conflicts BetweEn CONGRESS AND THE PRESIDENT 33 (4th ed. 1997) (noting that Senators may be able to block an appointment even in cases that do not require advice and consent and citing an example). 
advice and consent requirement. There are also informal relationships that would give the President the incentive to take some account of the Senate's views. Political party relationships, regional affiliations, and personal relationships all create ties between at least some Senators and the President such that the President might be expected to take account of their views. The President thus might still consult with the Senate on these matters, or at least hesitate to sign treaties or make nominations that the Senate would strongly oppose, for fear that the President would feel the effects of such a decision in other areas of the President-Senate relationship.

Notice further that the set of cases where the outcome might change by elimination of the Senate's advice and consent functionthat is, where the treaty or nominee would have been rejected, or not proposed in the first place, if Senate approval were necessary-is likely to be relatively small. The cases where the outcome could be different without Senate advice and consent are those cases where there are systematic differences in the views of the President and the Senate. Here, of course, is the assumption at the root of concerns about aggrandizement. But that assumption is problematic. Of course there are many differences between the branches, but demonstrating that those differences are systematic, and that their effect can thus be predicted, is difficult.

Consider this in the context of the advice and consent example. The factors that influence the Senate and the executive on policy questions are often not systematically differentiated. Treaties and nominations are events that particular groups, and their representatives in government organizations and interest groups, care about. If the treaty relates to human rights, a predictable mix of interest groups will present their views on the treaty, and these groups are likely to have some influence with both the executive and the Congress. There may be periods in time where there are systematic differences in interest groups' ability to influence decisions in the executive and the Senate, and that fact will produce cases where there will be differences in views between the executive and the Senate. But, although this is a complicated question, it seems most probable that such differences will relate to ideology-for instance, one party controlling Congress and another controlling the executive. If that is the case, such differences will not be stable across time and cannot be used as a basis for predicting the effect of an arrangement. ${ }^{102}$

${ }^{102}$ It is a common intuition that there are systematic differences between the 
My claim here is not that eliminating the Senate's advice and consent would be irrelevant to outcomes. The effort, rather, is to test our ability to predict outcome difference in a supposedly easy case. Even in that case, it is not obvious that we can predict a significant outcome difference-that is, that we will have many treaties and nominees that we would not otherwise have had. And even if we are convinced that outcomes would be changed by this hypothetical arrangement, certainty about this case is of no help in predicting outcome differences in other cases. Whether outcomes will be altered as a result of typically contested cases is even murkier.

Consider, for example, the common claim that the line-item veto strengthens the President at the expense of Congress. ${ }^{103}$ This claim is dependent, like the advice and consent example, upon systematically different views between the two actors. Put aside the complications just raised about this assumption and accept that those differences exist. The claim is that, as a result of the line-item veto, certain outcomes systematically favored by Presidents (and disfavored by Congress) will be achieved that would not be achieved without the lineitem veto. But is that so? Even with the line-item veto, Congress designs the legislative package that it sends to the President and it should have at least some ability to predict the President's reaction to

branches, differences that spring from institutional placement and thus are stable over time. Such differences would be the basis for a claim that a change in the allocation of decisionmaking authority would change outcomes. To support that claim, many would point to the different views that officials hold depending on their institutional placement. It is true, when the question relates to the prerogatives of the office, that institutional placement has a predictable influence on the views of the office occupants. Most Presidents have expansive views of executive power, and most members of Congress have expansive views of the investigative powers of the Congress. See FiSHER, supra note 101, at 160-95 (describing conflicts between the Congress and the President over access to information). That these sorts of differences in view exist, however, does not mean that there will be differences in outcome if decisionmaking authority is reallocated. No Senator would want the advice and consent requirement eliminated; it does not follow that eliminating it would lead to materially different outcomes.

${ }^{103}$ Some applaud this strengthening of the President; others lament it. See Calabresi, supra note 80 , at 78-81 (supporting the line-item veto because it would counteract congressional tendency to channel resources to individual districts that are inefficient and paid for by the nation as a whole). But see Bellamy, supra note 81, at 590-91 ("The item veto would change the balance-dramatically increasing the President's influence and control over the agenda of government and at the same time proportionally weakening Congress' ability to influence spending .... [P] rudence would suggest avoidance of structural tinkering."); Stearns, supra note 69, at 401, 418-20 (arguing that the line-item veto shifts the balance of power, thereby "providing the President with powerful opportunities to influence the direction and shape of legislative priorities, while affording him surprisingly little opportunity to excise the dreaded pork [barrel legislation]"). 
proposals contained in such packages. If these two things are true, then, as Professor Glen Robinson has pointed out, Congress can extract a promise from the President that if Congress includes a provision that the President favors, the President, in turn, will not veto the provision that the coalition in Congress wants to include in the bill. ${ }^{104}$ The President can, of course, go back on that promise, but not very often.

The difficulty of predicting the effect of an arrangement goes further than this. The mechanism by which the change in outcome will occur is usually unspecified. Consider, for instance, the claim that the independent counsel weakens the executive. ${ }^{105}$ Concretely, the claim must be that the President will not be able to achieve outcomes that he might otherwise achieve. But by what mechanism will the President's inability to control the appointment and removal of an independent counsel investigating high-level illegality prevent the President from exercising his authority in ways that he otherwise would? Will the President's inability to control the independent prosecutor somehow make the President unlikely to exercise the veto in the way he otherwise would, or hesitant to propose domestic policy initiatives? That is what critics of the independent counsel have in mind, but such claims seem speculative, at best. The existence of the independent counsel does not change the underlying incentives the President has to exercise his prerogatives in particular ways. Those incentives spring from a complex set of factors, including, at a minimum, the President's ideology, the line-up of the affected constituencies, the salience of the issues, and the timing within the election cycle. How an independent counsel changes those factors is obscure.

The independent counsel illustrates yet another difficulty with determining whether an arrangement leads to a changed relationship between the branches. Assume, for the moment, that we have a tool that discerns whether outcomes will change as a result of an arrangement and that we could see that the outcome change systematically favored one branch. At what point in time should we measure the fortunes of the branch? Assuming that there is a mechanism by which

${ }^{104}$ Robinson, supra note 69, at 417-18.

${ }^{105}$ See Calabresi, supra note 80, at 93-94 (noting that the existence of the Independent Counsel inevitably leads to more frequent and politicized investigations and that the existence of such investigations "encourages an excessive distrust of the government and of government officials, and it prevents government from addressing the real problems of the nation"); Calabresi, supra note 70, at 523-24 ("[T] he net effect of [Independent Counsel investigations] is to weaken the presidency relative to Congress."). 
the creation of an independent counsel will affect the President's actions, there may be a difference in the short-term and the long-term effect of an arrangement. ${ }^{106}$ Perhaps, initially, removing the appearance of self-interested investigation of high-level illegal activity through the mechanism of the independent counsel has actually strengthened the Presidency. But, in the long term, such a device might weaken the Presidency by inevitably leading to more investigations that distract officials and-though this seems to me highly speculative-chill the robust assertion of presidential prerogatives. ${ }^{107}$ Administrative agencies provide another example of this shortterm/long-term problem. In the short run, the creation of the administrative state may have strengthened Congress because the agencies were viewed as creatures of Congress. But, as these agencies have come to be viewed as parts of the executive branch, it may be that the administrative state has strengthened the Presidency. ${ }^{108}$

The final difficulty with claims about the comparative power of the branches of government is the deepest. An important assumption embedded in the inquiry is that it is sensible to think about a branch being aggrandized, or branches being balanced. As noted earlier, stating that a branch is dangerously aggrandized by a particular arrangement is tantamount to saying that the systematic outcomes-and constituencies-favored by that branch are more likely to result. This assumption-that there are branch-specific interests-supports the claims that particular devices will create an imbalance of power among the branches. It also supports the more generalized claims

100

Cf. Cass R. Sunstein, Bad Incentives and Bad Institutions, 86 GEO. L.J. 2267, $2267-$ 68 (1998) (arguing that " $\mathrm{t}]$ he Independent Counsel Act is a case study in the law of unintended consequences" since it "was designed to increase trust in government... [but] actually reduces trust in government, not because of serious misconduct on the part of high-level officials, but because of scandal mongering, and because of the transformation of political disputes into criminal allegations").

${ }^{107}$ See Calabresi, supra note 80, at 92-95 (arguing that the creation of the Independent Counsel led to more frequent and more politicized investigations); Calabresi, supra note 70, at 523-24 (urging that the presidency is weakened relative to Congress by Independent Counsel investigations).

${ }^{108}$ See Elena Kagan, Presidential Administration, 114 HARV. L. REV. 2245, 2272-315 (2001) (recounting the successful efforts of modern Presidents, especially President Clinton, to assert control over administration); Peter L. Strauss, From Expertise to Politics: The Transformation of American Rulemaking, 31 WAKE FOREST L. REV. 745, 750-72 (1996) (tracing the history of agency rulemaking from 1946 and demonstrating the executive branch's increasing effort and ability to control agency policymaking). 
that the executive is the "net beneficiary" of changes over time. The relevant units of measurement are the branches of government and they are assumed to have unitary interests. To illustrate with a specific example, the claim that the legislative branch is aggrandized by the legislative veto is to say that there is an identifiable legislative-branch interest that, with the addition of the legislative veto, will prevail more often than it otherwise would.

But talking about branches of government as if they have unitary interests is fantasy. We know that they are not unitary entities with identifiable branch-specific interests. They are complex institutions that are made up of many subparts; those subparts have varying interests that do not always coincide with one another. ${ }^{109}$ This is of course something we know: there are heated intra-institutional battles within the Congress and the executive branch, and, likewise, there is collaboration across branches of government when the interests of the subparts of those institutions coincide. ${ }^{110}$ There are numerous theories

${ }^{109}$ See generally MiChaEl FOLEY \& JOHN E. OWENS, CONGRESS ANd THE PRESIDENCY: InSTITUTIONAL POLITICS IN A SEPARATED SYSTEM (1996) (exploring the changes in Congress and the presidency in the recent decades in the context of other political developments and the importance of institutions within the political system); HERSMAN, supra note 100, at 5-6 (noting how "institutional fragmentation and ideological polarization sharply limit strong institutional leadership over foreign policy" and that "[s] uch individualism on the part of members of Congress is not new"); HENRY J. MERRY, FIVE-BranCH GoVERnMENT: THE Full MEASURE OF CONSTITUTIONAL CHECKS AND BALANCES 7 (1980) (explaining that the "belief that the branches are monolithic entities ... is far from the actual condition of things"); HAROLD SEIDMAN, Politics, Position, and Power: The Dynamics of Federal Organization 217 (5th ed. 1998) (arguing that "in the choice of institutional types and structural and procedural arrangements, we are making decisions with significant political implications").

${ }^{110}$ See, e.g., Roger H. DAVIdSON \& WALTER J. OleszeK, CONGrESS AGainst ITSElF (1979) (analyzing the battle over procedural reform in the House of Representatives and demonstrating intra-branch disagreement); HERSMAN, supra note 100 , at 7-8, 65, 83 (describing the role of cross-institutional collaboration and intra-branch disagreement in foreign policy case studies); DAvID C. KING, TURF Wars: HOW CONGRESSIONAL COMMITTEES CLAIM JURISDICTION 105-147 (1997) (studying in depth the intra-branch battles within Congress over committee jurisdiction); MERRY, supra note 109 , at 10, 24, 33-34 (noting that subunits of executive and legislative branches, along with relevant interest groups, collaborate with one another); JAMES $Q$. WILSON, BUREAUCRACY: WHAT GOVERNMENT AGENCIES DO AND WHY THEY DO IT 202-05 (1989) (noting that the key to agency officers' success is location of external constituencies wherever they may be found, including key committees and members in Congress, other parts of the executive, or important interest groups); Daryl J. Levinson, Making Government Pay: Markets, Politics, and the Allocation of Constitutional Costs, 67 U. CHI. L. REV. 345, 356 (2000) (observing that government is a multilayered collection of politicians and bureaucrats with different, and often conflicting, goals and agendas); Nelson Lund, Rational Choice at the Office of Legal Counsel, 15 CARDOZO L. REV. 437, 491-96, 502 (1993) (recounting disputes between subparts of the Department of Justice and be- 
that support the basic point that the branches of government are not monolithic entities, and legions of examples that confirm the claim. ${ }^{11}$ Consider the most well known of the phenomena supporting the point: although the precise nature and effect of the relationships are the subject of debate, there is little doubt that there are cross-branch alliances between administrative agencies and the congressional committees that have jurisdiction over them, alliances fed and supported by the constituencies that are the objects of regulation by those government actors. ${ }^{12}$ Such cross-branch alliances sometimes mean that subparts of the two branches will work together toward common goals; this is so even though those goals might be opposed by other subparts of the institutions and are not endorsed by the larger institution within which those subunits operate.

The fact that branches are not singularly motivated entities, but rather are an amalgam of distinct entities and/or shifting coalitions that are not animated solely by their location in a particular branch makes claims about strengthening or weakening a "branch" problematic. First, the complexity of these institutions further compounds the difficulty of predicting anything systematic about the outcome effects of an institutional arrangement. An extreme example illustrates the point. If the Senate, rather than the President, had the power to remove Cabinet secretaries, one could argue that a particular institution-the Senate-would be strengthened. ${ }^{113}$ But what that would

tween the Department of Justice and the White House); Theodora Galacatos, Note, The United States Department of Justice Environmental Crimes Section: A Case Study of Interand Intrabranch Conflict over Congressional Oversight and the Exercise of Prosecutorial Discretion, 64 FORDHAM L. REV. 587, 628-52 (1995) (describing inter-branch and intrabranch disagreement over environmental crime programs).

"II For instance, the common rational choice model that explains bureaucratic behavior assumes that agency policymakers will seek, above all, to maximize the size of the agency's budget. William A. NiSKANEN, JR., BUREAUCRACY AND REPRESENTATIVE Government 159 (1971). Perhaps the most famous empirical regularity supporting the argument in the text is the so-called "iron triangle" among congressional committees, agency officials, and the constituent interests that are the target of regulation by those committees and agencies. See, e.g., FOLEY \& OWENS, supra note 109, at 208 (commenting on the "iron triangle" as evocative of a "permanent sub-government, independent of presidential direction, resistant to unacceptable change and largely autonomous in nature"); MERRY, supra note 109, at 80-86 (arguing that the specialinterest alliances composing an iron triangle are fundamental to policymaking).

${ }^{112}$ FOLEY \& OWENS, supra note 109 , at 208-09; MERRY, supra note 109 , at $80-86$; WILSON, supra note 110, at 251-52.

${ }^{119}$ The example is based on the Tenure in Office Act of 1867, which forbade the removal of certain Cabinet officers without the consent of the Senate. Tenure in Office Act, ch. 154, 14 Stat. 430 (1867). Andrew Johnson, of course, was impeached for defying the Act by discharging the Secretary of War without Senate approval. See gener- 
mean in terms of outcome effects is difficult to predict. Given that the Senate is made up of individuals with differing motivations and interests, and that its membership is not static over time, that strengthening may not mean anything systematically. Depending on the particular make-up of the Senate and the preferences of the President, the outcome of Senate control of removal might sometimes be the same as the outcome the President would have reached had he controlled the removal of Cabinet secretaries, and might sometimes be different than the outcome that the President would have reached. That is to say, given the complexity of each of the branches of government, claims to systematic differences among them are difficult to maintain.

The second implication of understanding the branches as multiinterested entities, rather than unitary bodies with systematic interests, is more important. Understanding this about the branches should make us less troubled by claims that a branch is strengthened or weakened. Recall that such claims are based on the view that the branches prefer different outcomes and that one branch's preferences will prevail more or less often under a particular arrangement. The special concern about imbalance is that interests that prefer a particular set of outcomes will be wrongly silenced or ignored (if they are the interests associated with the branch that is weakened), or will be inappropriately advantaged (if associated with the branch that is strengthened). ${ }^{14}$ It may be, as just argued, that the supposedly systematic differences among the branches are less systematic than conventional analysis assumes. But the point goes further; given the diversity of interests comprising the institutions, the chance that a particular set of constituencies will be consistently silenced or ignored, or consistently advantaged and preferred, is quite small. This is because the constituencies that have some influence in the branches before the change will continue to have some influence after the change.

ally MiChaEl LES BENEDICT, THE IMPEACHMENT AND TRIAL OF ANDREW JOHNSON (1973). In Myers $v$. United States, 272 U.S. 52, 176 (1926), the Supreme Court held that Congress could not constitutionally require the consent of the Senate for the removal of a postmaster who had been appointed by the President with the Senate's approval. For a discussion of Myers, see DAVId P. CuRRIE, THE CONSTITUTION IN THE SUPREME CourT: The SECONd CenTuRY, 1888-1986, at 193-95 (1990).

${ }^{114}$ Cf. Nourse, supra note 13 , at 759 ("[T] he constitutional danger in shifting functions lies in popular silences and amplifications, in empowering some constituencies at the expense of others.... [T] he problem with sending the war decision to the Court is ... the silencing of national and local constituencies on such an important issue...."). 
To see the point, consider a world in which the President does not have the veto power. We would say that the legislative branch was strengthened and the executive branch weakened because Congress no longer needed the approval of the President or a supermajority to approve a statute. The executive branch is weakened because it cannot now achieve a set of outcomes that it could achieve with the existence of the veto: certain bills would not be laws, others might be laws. Without the veto, that is, there are likely to be outcomes that cannot be achieved. Those are outcomes supposedly systematically favored by the executive branch and disfavored by the legislative branch. On a crude rendering of those differential outcomes, one predicated on the electoral base from which the bodies arise, the executive systematically will care more about constituencies with a national base, and the Congress more about constituencies with localized bases.

This rendering of the supposedly systematic differences among the branches operates, however, at too high a level of generality, and it therefore overstates the significance of a shift between the executive and the legislature. Both the executive and the legislative branches are composed of entities whose constituencies are more particularized than the national/local description. Thus, for instance, the United States Department of Agriculture (USDA) pays particular attention to the concerns of farmers, and the committees in the Senate and House with jurisdiction over agriculture do the same. ${ }^{115}$ Imagine that Congress has approved a statute providing significant subsidies to agriculture in a world where the President has no veto. That law was supported by a collection of interests-most important, of course, the winning coalition in Congress, but also by the USDA. If the President had a veto, the Secretary of Agriculture would have attempted to convince the President not to exercise the veto. Even so, assume that the President, if he had a veto, would have vetoed the bill. Thus, in the world without the veto, the bill is law. There is an outcome difference, but has some dangerous change in the balance of power occurred? That would be difficult to maintain. It is hardly as if the interests of farmers will disappear from the radar screen of government actors. Under a different President-say, one with an electoral base rooted in farm country-the nonexistence of the veto would not matter because the President, if he had the veto, would not have exercised

115 See generally JOHN P. Heinz ET AL., THE HOllow CORE: PrIVATE INTERESTS IN NATIONAL POLICYMAKING 35-43 (1993) (providing an overview of key interest groups in agriculture policy). 
it. The coalition in Congress will continue to be sympathetic to the farm constituency. And, despite the outcome in this case, the USDA remains a part of the executive branch and can be counted on to continue to urge the President to consider the needs of farmers.

The criticisms explored here expose the two central commitments of conventional approaches to separation of powers as flawed. What happens if we give up on that core? That is, is it possible to devise an approach to separation of powers that does not depend on distinguishing among the powers of government and treating the branches of government as entities that must be balanced with one another? To start that effort, Part II speculates on the implications of the arguments advanced in Part I. The good news is that taking seriously the criticism presented here offers a different, and perhaps more promising, way of guiding our understanding of separation of powers, one that forgoes reliance on the comfortable guides of the three powers and the three branches.

\section{BEYOND POWERS AND BRANCHES}

Conventional approaches to separation of powers aspire to identify and separate three different powers in three different branches and to assure that some appropriate level of authority is maintained among them. As Part I argued, both parts of that effort fail: the functions are difficult to distinguish and seem destined to blend together at the margins; and maintaining some supposedly appropriate allocation of authority among branches is a fruitless enterprise, in part because the very inquiry itself is incoherent-branches are not bodies with unitary interests, but are made up of diverse entities and individuals with varying concerns that do not simply correspond to branch affiliation. Without an understanding of how functions could be kept separate, or how branches could be kept balanced, conventional approaches have difficulty getting off the ground. We should see that enterprise for what it is, a failure, and abandon it.

That failure does not mean there are no helpful ways to think about the distribution of government authority within a separation of powers system. To be sure, reconstruction of separation of powers law will be difficult. Identifying the precise contours of that doctrine is beyond the scope of this Article. We cannot start that effort, however, without understanding exactly where current law goes wrong, and in 
that sense this Article contributes to that effort. But the criticisms offered here do more than clear the way for a reconceptualization of separation of powers law; they assist in that effort. Taking seriously some of the failings of current law not only reveals that we are asking the wrong questions, it helps identify the right ones.

Reconstructing separation of powers law must begin by recalling its aims. Most broadly, those aims are to fragment the exercise of government authority and to guarantee that fragmentation. A more finegrained appreciation of these objectives understands the effort to disperse power as having two distinct aspects. One is the diffusion of government authority among a number of decisionmakers in order to assure that no single decisionmaker (or institution) exercises all that authority. ${ }^{116}$ The point is familiar: having one, or even a few, actors controlling all government authority increases the risk that state power will be abused in some unquestionably awful way. What is important on this understanding is that a large enough range of decisionmakers share in the exercise of government authority. It does not much matter what we call the power those decisionmakers exercise; it just matters that government authority is diffused among them.

The effort to divide power and assure that it remains so divided also has another, more ambitious and complicated, component: matching the exercise of certain types of government authority with specific types of government decisionmakers. ${ }^{17}$ This aspect of the effort to fragment government authority is best illustrated by the widely held intuition that individualized disputes should be adjudged by decisionmakers who have a duty to be impartial and, at the federal level at least, are insulated from direct electoral politics. For this sort of effort to fragment power, the type of government power matters quite a bit because certain categories of government authority can be appropriately exercised only by corresponding decisionmakers.

Orthodox approaches to separation of powers seek to satisfy both these aims through the mechanisms analyzed in Part I. They aspire to identify and separate the three functions into three institutions and to assure some balance among those institutions. In theory at least, ad-

116 See REDISH, supra note 11, at 102-08 ("Mixed government was designed to prevent absolutism - the arbitrary use of power-by avoiding the concentration of all state power in one body."); Merrill, supra note 6, at 229, 246 (noting that "diffusion of power among the branches" is an important and traditional purpose of separation of powers).

${ }^{117}$ See, e.g., Currie, supra note 9, at 21-39 (identifying reasons why each of the three powers are to be exercised by their corresponding institutions). 
ity. ${ }^{118}$ That government decisionmakers will protect their turf may be intuitive, but that intuition is bolstered by the fact that these actors have diverse incentives, making the risk that a critical mass of them will collude to concentrate power (and hence be in a position to abuse that authority) quite slim. These government decisionmakers have varied ways of making policy decisions, operate under different selection and tenure rules and thus have distinct constituencies (electoral or otherwise), and are located within institutions and subinstitutions with separate internal organization and norms. The factors that push and pull those decisionmakers in different directions are about as multifarious as can be imagined. It is this kind of variation among multiple decisionmakers that supplies the kind of political culture that we have. This political culture surely has its drawbacks. It is far from cohesive; within its confines, it is even difficult to translate an overwhelming electoral mandate into dramatic policy change. ${ }^{119}$ But it also has advantages: it offers many points of entry in to the policymaking process and many types of decisionmakers with varied incentives resulting from their distinct constituencies, institutional location, and ways of doing business. Whatever its normative merits, however, this system exhibits the trait sought by the conventional approaches: within it, government authority is fragmented.

That we operate in a system where government authority is highly fragmented, and is likely to remain so, has significant implications for separation of powers doctrine. It means that a piece of that doctrine is just concerned with the wrong thing. When courts or commentators stress the importance of keeping the exercise of government functions in distinct branches, or assert that one branch will be aggrandized by an arrangement, one fear driving these claims is that the failure to separate functions or prevent aggrandizement will lead to dangerous concentrations of government power in one branch of

${ }^{118}$ See WiLSON, supra note 110 , at $179-95$ (exploring the ways in which agencies strive for autonomy and the consequences this has on government power).

119 See GIOVANNI SARTORI, COMPARATIVE CONSTITUTIONAL ENGINEERING: AN INQUIRY INTO STRUCTURES, INCENTIVES AND OUTCOMES 86-91, 88 (1994) (arguing that the United States' form of separation of powers produces "paralysis and stalemates"); Bruce Ackerman, The New Separation of Powers, 113 HARV. L. REV. 633, 642-48 (2000) (noting that in systems of separated powers there are problems of impasse that can lead to accommodation, constitutional breakdown, or a "crisis in governability"); see also DAVID R. MAYHEW, DIVIDED WE GOVERN: PARTY CONTROL, LAWMAKING, AND INVESTIGATIONS, 1946-1990 (1991) (arguing that there is little measurable difference in significant legislative output and frequency of congressional investigations based on unified or divided government). 
hering to the conventional approach would mean that power would generally be diffused among three government institutions and that diffusion would occur in a specific way: three different powers would be exercised by three corresponding branches. Of course, this Article has argued that we cannot tell the difference between the powers in contested cases and that there is no such thing as a branch in the sense assumed by conventional approaches. This might sound like bad news, but it is not; that critique offers important lessons for both parts of the fragmentation effort.

The most important lesson is that if one is interested in assuring that government authority is fragmented in a general way, the failure of the conventional approaches need not be lamented. It is true that we cannot identify the differences between the three powers and cannot speak coherently of balanced branches. But we do not need to succeed with that effort in order to achieve fragmented government authority. In the process of noticing that there is no such thing as three essential powers exercised by three undifferentiated entities called branches, we also should have noticed that, in fact, the exercise of government authority is highly fragmented-it is just not fragmented according to the three-powers-in-three-branches formula. Rather, we have a much more complicated form of fragmentation in the political system that has evolved. In that system, government authority is dispersed among a group larger than the usual suspects of the three branches. State power is diffused among an enormous, and diverse, array of decisionmakers who populate what we call the branches. Within Congress: a house committee chair; a ranking member of a Senate committee; and the deputy whip in the Senate or the majority leader in the House. Within the executive: an agency administrator; the director of the Office of Management and Budget; and a United States attorney. Within the judiciary: a magistrate judge; a bankruptcy judge; a district court judge; and appellate judges. Each of these decisionmakers plays some important role in the exercise of state power. If diffused government authority is what we are after, we have it, in spades.

This kind of fragmentation is complicated, even chaotic, but it is also our assurance against threatening concentrations of government power. These many and varied government actors can be counted on to protect their slice of decisionmaking authority, and, in that way, they will naturally work against concentrations of government author- 
government. ${ }^{120}$ At a doctrinal level, this concern about concentration of state authority arises in numerous contexts: courts and commentators debate whether administrative agencies represent an impermissible combination of government functions; ${ }^{121}$ whether the line-item veto strengthened the executive; ${ }^{122}$ whether the legislative veto aggrandized the Congress; ${ }^{123}$ or whether the executive has, as the result of changes over time, become "the most dangerous branch" such that Congress should be permitted to take action to counteract that phenomenon. ${ }^{124}$ Each of these debates is, in part, about whether a particular branch of government possesses or will accumulate excessive power. But once we recognize that government power can be, and is, diffused within a branch, and that fragmentation of state power need not (indeed cannot be comprehensibly understood to) be among branches, the concern that an arrangement concentrates power in a branch becomes anachronistic. Whatever else the line-item veto or the legislative veto would do-and perhaps there are separate reasons to be concerned about them-they would barely make a dent in the extensive fragmentation of government authority that exists. With or without those devices, government authority would remain diffused, widely so, among varied decisionmakers.

Whether state authority is fragmented at exactly the right level is a distinct and difficult question. Some claim that government authority is far too fragmented in our system. ${ }^{125}$ But trying to maintain the ideal

${ }^{120}$ For elaborations on this position, see REDISH, supra note 11, at 102-08; Calabresi \& Prakash, supra note 8, at 559-65; Currie, supra note 9, at 19; Greene, supra note 4, at 124; Lawson, supra note 8, at 1248-49; Magill, supra note 6, at 1183-84; Merrill, supra note 6 , at $229,251$.

${ }^{121}$ See Currie, supra note 9, at 19-20 (describing situations in which agencies appear to carry out executive, legislative, and judicial functions); Lawson, supra note 8 , at 1237-41 (arguing that modern administrative agencies exercise legislative powers).

${ }^{122}$ See Clinton v. City of New York, 524 U.S. 417, 451-52 (1998) (Kennedy, J., concurring) (contending that the Line Item Veto Act enhanced the executive's powers beyond the bounds of the Constitution); Devins, supra note 69, at 1624-25 (arguing that the line-item veto does not unduly strengthen the executive); Powell \& Rubenfeld, supra note 3, at 1196 (detailing how the line-item veto could strengthen the executive).

${ }^{123}$ See Froomkin, supra note 4, at 1368 (suggesting that the legislative veto aggrandizes Congress); Greene, supra note 4, at 165 (asserting that the Court's invalidation of the legislative veto can be explained by the principle that Congress may not aggrandize itself).

${ }^{124}$ See Calabresi, supra note 80, at 31-34 (reviewing arguments that the executive is now relatively weak compared to other branches); Eskridge \& Ferejohn, supra note 86, at $\mathbf{5 3 3}$ (arguing that there has been a shift in lawmaking power from Congress to the President); Flaherty, supra note 5, at 1727 ("Never has the executive branch been more powerful, nor more dominant over its two counterparts, than since the New Deal.").

${ }^{125}$ Such claims are the centerpiece of arguments against separation of powers sys- 
level of diffusion of state power would be a futile exercise. If the arguments contained in Part I.B are correct, it would not be possible to design a doctrine that guaranteed just the right level of dispersal of government authority. That enterprise would flounder in much the same way that the effort to balance the branches flounders; we would have to articulate an ideal level of fragmented power, identify the amount of fragmentation at any point in time, and predict whether an arrangement would threaten to undermine the appropriate level. To be sure, it is not incoherent to talk about achieving fragmentation of state power in the same way that it is incoherent to talk about maintaining a balance among branches. ${ }^{126}$ Even so, the other difficulties would prevent such an effort from being successful.

Despite the impossibility of designing a doctrine that perfectly polices the extent of the fragmentation of government authority, we should not miss the significance of the insight that we operate in a system where state power is widely distributed, albeit not only on the three-branch metric. Government authority is dispersed among many decisionmakers, and, given their varied incentives, the likelihood of that authority being consolidated in just a few hands is very small. Completely assessing or controlling the extent of that fragmentation is probably impossible. Nonetheless, the amount and character of that diffusion of state power should be more than sufficient to put to rest concerns about dangerous concentrations of power. Saying anything more precise than that is difficult. But saying that is quite important.

The lesson for the more finely tuned aspect of the fragmentation effort is more modest. That aspect aspires to something more than generic diffusion of state power among varied decisionmakers; state power must be dispersed in a particular way-that is, certain types of

tems. See, e.g., SARTORI, supra note 119, at 91 (arguing that "Americans do have a constitutional machine made for gridlock; a defect that shows in all its might when their presidentialism is exported"); SEPARATION OF POWERS-DOES IT STILL WORK? (Robert A. Goldwin \& Art Kaufman eds., 1986) (examining the argument that the constitutional separation of executive and legislative powers hinders the government's ability to make domestic and foreign policy and to maintain a strong national defense); Ackerman, supra note 119, at 642-53 (examining the disadvantages of the American system of an independently elected executive).

${ }^{126}$ See supra notes 109-15 and accompanying text (arguing that claims about balance among the branches are incoherent because the branches are not unitary entities with identifiable interests). 
power must be matched with certain types of decisionmakers. ${ }^{127}$ There are complicated, sometimes unstated, reasons for these matches. Beliefs about the correspondence between a power and a decisionmaker are based on intuitions about the suitability of types of decisionmakers (a single person, rather than a collegial body, must decide this sort of question) ${ }^{128}$ or normative convictions, such as what liberal democracy requires (a multimember, broadly representative, elected body must make this kind of decision). ${ }^{129}$ In pursuit of this type of fragmentation, conventional approaches to separation of powers seek to identify the three government functions and make certain that they are exercised by the corresponding institution. But we cannot possibly assure the right union between power and branch because, as Part I argued, we cannot tell the difference between the powers in contested cases and we should not think of institutions as if they were monolithic entities. That does not mean that there are no useful ways to think about what types of decisionmakers should exercise different kinds of government authority. It will just make us see that effort in a new light.

Matching the exercise of certain types of power with corresponding decisionmakers is, to say the least, an ambitious undertaking. Assertions that some actors are most capable of, or normatively required to, exercise particular state powers entail a host of difficult and vexing questions. At the broadest level, those questions include: Which policy judgments must the legislature make and which can be left to those who implement the law?; ${ }^{130}$ What sorts of decisions should, or

${ }^{127}$ See Currie, supra note 9, at 21-23, 31-32, 37 (describing and explaining why three powers are assigned to the legislature, the executive, and the judiciary).

128 Allocating government authority based on institutional competence is classically associated with the legal process school. See William N. Eskridge, Jr. \& Philip P. Frickey, Introduction to HENRY M. HART, JR. \& AlBERT M. SACKS, THE LEGAL PRoCESS: BASIC PROBLEMS IN THE MAKING AND APPLICATION OF LAW, at li, lx-lxi, xci-xcvi (William N. Eskridge, Jr. \& Philip P. Frickey eds., 1994) (stating that the book "incorporate[s] the idea of comparative institutional competence”). Professor Currie is an example of a separation of powers commentator who draws on that tradition. See Currie, supra note 9, at 31 (stating that the executive power was vested in the President, inter alia, because of "the need to concentrate executive power in the hands of a single person").

${ }^{129}$ See Currie, supra note 9, at 22 (stating that legislative power was vested in the Congress because "it was important to give some substantial role in lawmaking to a body directly elected by the people" and because of "the value of having legislative decisions made by a collective body in which various interests were represented"); Lawson, supra note 8, at 1239 (describing the core of the Constitution's nondelegation principle as providing that "Congress must make whatever policy decisions are sufficiently important to the statutory scheme at issue so that Congress must make them").

${ }^{190}$ This is the question at the heart of debates over the appropriateness and wis- 
should not, be made by decisionmakers who enjoy the independence afforded federal judges? ; $^{131}$ Is the President best suited to have expansive powers over foreign affairs and military action? ${ }^{132}$ Answers to those questions depend on contested normative convictions and complicated empirical assessments. But it is these sorts of questionsalbeit sometimes in less elevated form, as in whether administrative agencies can adjudicate controversies or whether an independent counsel is permissible-that lurk in the background of disputes about the proper allocation of government authority. Those questions will obviously remain contested for years to come.

That these questions are vexing does not mean that they should not be asked. But current separation of powers doctrine asks them in the wrong way. The critique offered here identifies a particular failing of the questions we ask in our effort to assure the appropriate assignment of government authority and simultaneously suggests the more promising questions. The basic failing is a mismatch between the nature of the distribution of government authority and the doctrine that purports to evaluate that distribution. Our system operates not at the level of powers or branches but at the more particular level of government decisionmaker. State power is dispersed among a large, and diverse, set of government decisionmakers; what they do cannot neatly be sorted into three categories of power, nor can their branch affiliation be considered the determinative factor in how they will make their decisions. But current doctrine operates as if there were essential powers called legislative, executive, and judicial power that can be appropriately matched with branches called the legislative, executive, and judicial branches. Those inquiries, as Part I argued, are fruitless. But the point goes beyond that; for a doctrine that seeks to assure a suitable assignment of government authority among varied actors,

dom of the congressional delegation of policy questions to administrative agencies. The prime modern work, which characterizes congressional delegation as abdication of the most serious sort, is THEODORE J. LOWI, THE END OF LIBERALISM (1969).

${ }^{131}$ Questions about the independence and role of the federal courts arise in many contexts, most prominently in the debate over the advisability and proper scope of judicial review. The familiar classics of this debate include ALEXANDER M. BICKEL, THE LeAst Dangerous Branch: THE Supreme Court at THE Bar OF POLITICS (1962) and JOHN HART ELY, DEMOCRACY AND DISTRUST: A THEORY OF JUDICIAL REVIEW (1980).

192 Again, this is the question at the center of many long-standing disputes. See JOHN HART ELY, WAR AND RESPONSIBILITY (1993) (arguing that Congress has unconstitutionally abdicated its responsibility to make decisions about entry into war and ceded that role to the executive); Peter M. Shane \& Harold H. Bruff, Separation of POWERS LAW 585-854 (1996) (surveying disputes regarding allocation of authority between Congress and the President on foreign affairs and war powers). 
that abstract and lofty level is off track. The categories do not meaningfully describe the powers exercised, nor does the doctrine ask questions that help predict how government authority will be exercised. In other words, the doctrine should descend from its perch and focus on the fact that it is government actors, not powers and branches, that matter.

Before we can determine how state power should be distributed among varied government decisionmakers, we first need to know how those decisionmakers have or will exercise authority. To do that, we need to understand how officials exercise their authority. This requires a different analysis than the powers-and-branches approach that current doctrine contemplates. Under the structure of current doctrine, the debate about the legislative veto focuses on whether a subset of the Congress was given the power to legislate. ${ }^{139}$ Discussion of the permissibility of the line-item veto centered, in part, on whether it gave the executive the power to legislate. ${ }^{134}$ The disputes about the United States Sentencing Commission and the independent counsel followed a slightly different pattern: they focused not on a characterization of the type of power exercised, but instead on whether those arrangements undermined the exercise of the relevant branch's function. $^{195}$ But analyzing any of these questions by characterizing the power exercised and discerning whether it is in the right branch, or even asking whether, as in the case of the independent counsel or the Sentencing Commission, the arrangement interfered with the branch's exercise of its function, is the wrong way to think about them. These questions send us looking in the wrong direction-trying to define the meaning of executive power, or to identify a core function of a branch and judge whether it is threatened. Those in-

${ }^{193}$ See INS v. Chadha, 462 U.S. 919, 946-51 (1983) (holding the legislative veto to be unconstitutional because it effectively allowed one house of Congress to legislate on its own).

${ }^{134}$ See Clinton v. City of New York, 524 U.S. 417, 451-52 (1998) (Kennedy, J., concurring) (arguing that the line-item veto is unconstitutional in that it gives the executive power to legislate); Powell \& Rubenfeld, supra note 3, at $1172-80$ (giving arguments on both sides of the debate over whether the line-item veto gives the power to legislate to the executive).

${ }^{135}$ Mistretta v. United States, 488 U.S. 361, 380-97 (1989) (holding that Congress did not violate the separation of powers doctrine by placing the Sentencing Commission in the judicial branch); Morrison v. Olson, 487 U.S. 654, 689-96 (1988) (holding that the power of the Special Division of the Court of Appeals for the District of Columbia Circuit, a court created by the Ethics in Government Act, to terminate an Independent Counsel's office is not a significant judicial encroachment upon executive power). 
quiries do nothing to help us determine how state authority is likely to be exercised. To do that, we need to focus on the incentives of government actors. And that focus must be not at the level of a branch of government, but at a less elevated level, one that is meaningful to those government actors. Such analysis would work much closer to the ground-investigating the relevant decisionmakers, the context in which they act, the process by which they will reach their decisions, and the constraints on their actions.

To see how such a doctrine might look, consider the question of the permissibility of the mix of powers that many administrative agencies exercise. Within the framework of conventional approaches, there are two competing questions to ask. For some, that debate should center on whether such agencies exercise solely the power assigned to the branch in which they sit, that is, executive power, or whether they also impermissibly exercise judicial power (owing to their authority to adjudicate controversies) and legislative power (because of the broad discretion they have to formulate the law). ${ }^{136}$ For those skeptical of such functional niceties, the relevant question is whether the mix of powers those agencies exercise serves to undermine the core functions of the executive, legislative, or judicial branches. ${ }^{197}$ But both routes are off track. To evaluate whether an administrative agency should be permitted to exercise a range of powers, first we need to understand how the agency does or can be expected to exercise those powers. Labeling the powers or asking whether, in some broad-brush way, a branch is threatened by the ar-

1966 See, e.g., Commodity Futures Trading Comm'n v. Schor, 478 U.S. 833, 859-67 (1986) (Brennan, J., dissenting) (arguing that adjudication of a state-law counterclaim by an administrative tribunal is an unconstitutional exercise of judicial power by a nonArticle III entity); Lawson, supra note 8, at 1237-41 (arguing that administrative agencies often exercise legislative power and should be unconstitutional for that reason); supra notes 10-17 and accompanying text (surveying, inter alia, formalist position, which would ask the question identified in the text); $c f$. Morrison v. Olson, 487 U.S. 654, 705-10 (1988) (Scalia, J., dissenting) (arguing that prosecution is an executive function and therefore the President must be able to fire at will a prosecutor exercising that power).

${ }^{137}$ Independent agencies arguably threaten the integrity of each branch: the executive because of appointments arrangements that limit the President's ability to fire at will officials who head those agencies; the legislative because of the expansive discretion agencies can have to implement the law; and the judicial because of the adjudicatory functions some agencies are assigned. For examples of this undermine-the-branch reasoning in the context of administrative agencies, see Schor, 478 U.S. at 851-52, which upheld adjudication of a state-law counterclaim by an administrative tribunal because, inter alia, such adjudication did not impermissibly threaten the institutional integrity of the judicial branch; and Strauss, supra note 9, at 640-66. 
rangement, does not help us do that. Instead, we should seek to understand the incentives of the actors who will exercise that power in a pointed enough way that it helps us comprehend how those powers will be exercised. Some legal observers pursue this kind of analysis, but far too few. ${ }^{138}$ A sufficiently grounded inquiry into officials' incentives requires a contextual investigation of how state power will be exercised: understanding the organization of the agency; the process by which its actors will make decisions; and the constraints on its decisionmaking. ${ }^{139}$ At a minimum, the analysis must take account of the complicated web of subconstitutional law that governs the actions of agencies, ${ }^{141}$ given that such constraints importantly shape the way agency authority is exercised. This is not to suggest that understanding how government actors are likely to exercise authority will be easy. It will not be. But focusing the doctrine in this way will at least move it in the right direction.

Compared to the enormity of the questions sometimes at stake in the effort to achieve the right match between the government authority and the government decisionmaker, the teaching of this Article is modest. It does not supply answers to the fundamental questions that

${ }^{138}$ Assessing the advisability of an allocation of state power can of course start with a close study of how that power has been exercised. In an influential study, Professors Bruff and Gellhorn did just that with the legislative veto. Harold H. Bruff \& Ernest Gellhorn, Congressional Control of Administrative Regulation: A Study of Legislative Vetoes, 90 Harv. L. REv. 1369, 1381-1423 (1977). Likewise, Professor Martin's arguments against the legislative veto are informed by an appreciation of the way those vetoes operated in practice. David A. Martin, The Legislative Veto and the Responsible Exercise of Congressional Power, 68 VA. L. REv. 253, 267-93 (1982). When an arrangement is new and must be evaluated, such empirical work is not possible. But one can still make judgments about how an official or entity might exercise government authority by trying to understand the key officials' likely incentives. A few legal analysts evaluate the distribution of government authority based on the likely behavior of the officials who will exercise that authority. See, e.g., Calabresi, supra note 80, at 34-35 (arguing for a strong executive based on the incentives of the President); Nourse, supra note 13, at 757-68 (examining departmental power as sets of political relationships between the public and the government, rather than as sets of tasks).

${ }_{139}$ See NISKANEN, supra note 111, at 45-77 (applying the methods of economics to develop a theory of the behavior of bureaus in a representative government); WILSON, supra note 110, at 27-28 (attempting to explain the behavior of bureaucracies in terms of their organizations, operators, managers, and executives); Levinson, supra note 110 , at 380-87 (arguing that in order to predict agency behavior, one must take account of the agency relationship between elected officials and bureaucrats).

140 Many general statutes constrain agency activities; the most prominent one is the Administrative Procedure Act, 5 U.S.C. $\$ \$ 551-706$ (1994). Agencies are also constrained by other general instruments, such as executive orders that direct how agencies will conduct their business, as well as the specific statutes that create the agency and grant it the authority to act in specific areas. 
underpin disputes about the proper allocation of government authority. There are no clean answers here about the great questions-the appropriate division of policymaking between the Congress and the executive, or the proper role of the judiciary in a representative democracy. Nor are there clear answers about the less elevated manifestations of those questions: Should administrative agencies be permitted to adjudicate disputes arising under the laws they administer?; Is an independent counsel permissible? The reward for the effort is more incremental; the insight is that a reconstructed separation of powers doctrine must ask a different set of questions than it does now when it is seeking to match the exercise of classes of government authority with corresponding decisionmakers. Finally answering the fundamental questions may be far off, but we will not get any closer until we start asking questions that point us in the right direction.

\section{CONCLUSION}

This Article has argued that the two central commitments of contemporary separation of powers doctrine are failures and should be recognized as such. Talk of three separate powers exercised by three balanced branches is familiar, achingly so. It is also an unhelpful way to evaluate whether an institutional arrangement is constitutional. The burden of this Article is that it is time to give up on these ideas in favor of new ways of thinking about separation of powers law. Fortunately, understanding exactly where current doctrine goes wrong provides critical insights into the ways a revised doctrine could go right. The sketch of the reconstructed separation of powers law contained here concludes that we should stop worrying about some questionsbecause they focus on false threats-and that we should worry about the others by asking a different, less lofty, set of questions. 